NASA/TM-2007-214932

AIAA-2007-0900

\title{
Observations on the Growth of Roughness Elements Into Icing Feathers
}

Mario Vargas

Glenn Research Center, Cleveland, Ohio

Jen-Ching Tsao

Ohio Aerospace Institute, Brook Park, Ohio 


\section{NASA STI Program . . . in Profile}

Since its founding, NASA has been dedicated to the advancement of aeronautics and space science. The NASA Scientific and Technical Information (STI) program plays a key part in helping NASA maintain this important role.

The NASA STI Program operates under the auspices of the Agency Chief Information Officer. It collects, organizes, provides for archiving, and disseminates NASA's STI. The NASA STI program provides access to the NASA Aeronautics and Space Database and its public interface, the NASA Technical Reports Server, thus providing one of the largest collections of aeronautical and space science STI in the world. Results are published in both non-NASA channels and by NASA in the NASA STI Report Series, which includes the following report types:

- TECHNICAL PUBLICATION. Reports of completed research or a major significant phase of research that present the results of NASA programs and include extensive data or theoretical analysis. Includes compilations of significant scientific and technical data and information deemed to be of continuing reference value. NASA counterpart of peer-reviewed formal professional papers but has less stringent limitations on manuscript length and extent of graphic presentations.

- TECHNICAL MEMORANDUM. Scientific and technical findings that are preliminary or of specialized interest, e.g., quick release reports, working papers, and bibliographies that contain minimal annotation. Does not contain extensive analysis.

- CONTRACTOR REPORT. Scientific and technical findings by NASA-sponsored contractors and grantees.
- CONFERENCE PUBLICATION. Collected papers from scientific and technical conferences, symposia, seminars, or other meetings sponsored or cosponsored by NASA.

- SPECIAL PUBLICATION. Scientific, technical, or historical information from NASA programs, projects, and missions, often concerned with subjects having substantial public interest.

- TECHNICAL TRANSLATION. Englishlanguage translations of foreign scientific and technical material pertinent to NASA's mission.

Specialized services also include creating custom thesauri, building customized databases, organizing and publishing research results.

For more information about the NASA STI program, see the following:

- Access the NASA STI program home page at http://www.sti.nasa.gov

- E-mail your question via the Internet to help@sti.nasa.gov

- Fax your question to the NASA STI Help Desk at 301-621-0134

- Telephone the NASA STI Help Desk at 301-621-0390

- Write to: NASA Center for AeroSpace Information (CASI) 7115 Standard Drive Hanover, MD 21076-1320 
NASA/TM-2007-214932

AIAA-2007-0900

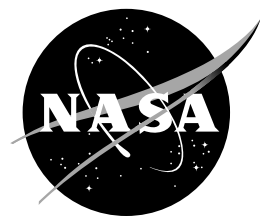

\section{Observations on the Growth of Roughness Elements Into Icing Feathers}

Mario Vargas

Glenn Research Center, Cleveland, Ohio

Jen-Ching Tsao

Ohio Aerospace Institute, Brook Park, Ohio

Prepared for the

45th Aerospace Sciences Meeting and Exhibit

sponsored by the American Institute of Aeronautics and Astronautics

Reno, Nevada, January 8-11, 2007

National Aeronautics and

Space Administration

Glenn Research Center

Cleveland, Ohio 44135 


\section{Acknowledgments}

The authors would like to thank Mr. David W. Sheldon for his help with the design of the model setup.

Level of Review: This material has been technically reviewed by technical management.

Available from

NASA Center for Aerospace Information

7115 Standard Drive

Hanover, MD 21076-1320
National Technical Information Service 5285 Port Royal Road Springfield, VA 22161 


\title{
Observations on the Growth of Roughness Elements Into Icing Feathers
}

\author{
Mario Vargas \\ National Aeronautics and Space Administration \\ Glenn Research Center \\ Cleveland, Ohio 44135 \\ Jen-Ching Tsao \\ Ohio Aerospace Institute \\ Brook Park, Ohio 44142
}

\begin{abstract}
This work presents the results of an experiment conducted in the Icing Research Tunnel at NASA Glenn Research Center to understand the process by which icing feathers are formed in the initial stages of ice accretion formation on swept wings. Close-up photographic data were taken on an aluminum NACA 0012 swept wing tip airfoil. Two types of photographic data were obtained: time sequence closeup photographic data during the run and close-up photographic data of the ice accretion at the end of each run. Icing runs were conducted for short ice accretion times from 10 to $180 \mathrm{sec}$. The time sequence closeup photographic data was used to study the process frame by frame and to create movies of how the process developed. The movies confirmed that at glaze icing conditions in the attachment line area icing feathers develop from roughness elements. The close-up photographic data at the end of each run showed that roughness elements change into a pointed shape with an upstream facet and join on the side with other elements having the same change to form ridges with pointed shape and upstream facet. The ridges develop into feathers when the upstream facet grows away to form the stem of the feather. The ridges and their growth into feathers were observed to form the initial scallop tips present in complete scallops.
\end{abstract}

\section{Nomenclature}

$\begin{array}{ll}\text { Al-NACA } 0012 & \text { Aluminum NACA 0012 swept wing tip airfoil } \\ \mathrm{d}_{\text {crit }} & \text { Critical distance, } \mathrm{mm} \\ \Lambda & \text { Sweep angle, degrees } \\ \mathrm{V} & \text { Velocity, mph } \\ \mathrm{T}_{\text {total }} & \text { Total temperature, }{ }^{\circ} \mathrm{F} \\ \mathrm{LWC} & \text { Cloud liquid water content, } \mathrm{g} / \mathrm{m}^{3} \\ \mathrm{MVD} & \text { Water droplet median volume diameter, } \mu \mathrm{m} \\ \tau & \text { Ice accretion time, minutes } \\ \mathrm{SLD} & \text { Supercooled Large Droplets } \\ \mathrm{IRT} & \text { Icing Research Tunnel }\end{array}$

\section{Introduction}

Icing feathers are the main components forming ice accretions on swept wings. In complete scallops the whole ice accretion is made of feathers and their interactions. In incomplete scallops only part of the ice accretion is made of feathers, the scallop tip. In no-scallops feathers may be present although they do not form scallop tips. The distance from the attachment line to where the feathers first start forming defines the critical distance, the key parameter measured in scallop formation. Because feathers play such 
a critical role in the formation of ice accretions on swept wings, icing physics studies are now focusing on gaining a more detailed understanding of how feathers initiate and develop. These observational studies will provide basic data for modeling feather formation.

Previous work on scallop formation (refs. 1 to 6 ) showed that in the initial stages of scallop formation the ice accretion is covered with large roughness elements and that feathers develop from those roughness elements. The detailed work for those observations was done with runs at ice accretion times from 10 to $120 \mathrm{sec}$ at 10 -sec intervals. At the end of each run photographic data was obtained. The overall characteristic of the process was captured but the detail occurring in the intermediate $10 \mathrm{sec}$ was not. In the case of the initiation of the feathers, the observations showed that the roughness elements develop into feathers but the detailed steps of how this occurs were not observed. Further observations are needed to determine if there are intermediate steps in the development of the roughness elements into feathers that need to be considered in the modeling of feather initiation.

This report presents the results of an experiment conducted in the Icing Research Tunnel at NASA Glenn Research Center to obtain photographic data on how icing feathers initiate on a NACA 0012 swept wing tip. The objective of the investigation was to answer the following research question: what is the actual process by which roughness elements develop into feathers and form scallop tips in the initial stages of the ice accretion formation on a swept airfoil?

To study the process, time sequence close-up photographic data was obtained from cameras located on the ceiling of the tunnel. Additional close-up photographic data was obtained of the final ice accretion at the end of each run. Most of the data was taken with digital cameras but $35 \mathrm{~mm}$ film cameras were used in selected cases. The time sequence photographic data was taken at 2, 3 and/or 5 sec intervals during each run. The raw data was studied frame by frame with digital imaging software programs. Digital movies were also created to observe the dynamic elements in the process. Two main icing conditions were tested. The conditions were chosen so that the ice accretion was a complete scallop. Typically for each condition an initial run of 2 or 3 min was conducted, and then shorter ice accretion times were run, starting at $10 \mathrm{sec}$ and increasing to $180 \mathrm{sec}$. To facilitate the close-up photography, two different positions of the airfoil in the test section were employed with one of them bringing the area of observation on the airfoil closer to the cameras located in the tunnel ceiling. A limited number of the observations were conducted at large droplet sizes (SLD conditions). Those SLD cases confirmed the observations made at appendix $\mathrm{C}$ icing conditions and provided additional key information on how a complete scallop develops from roughness elements to ridges, to feathers, to the formation of scallop tips.

Although photographic observations allow only a qualitative view of how the process occurs, they are a critical first step to gain an understanding of the process. The observations will lead to further experiments to quantify the process and they will help determine what research steps are needed to model the formation of ice accretions on swept wings.

\section{Experimental Procedure}

\section{A. Icing Research Tunnel}

The IRT is a closed-loop refrigerated wind tunnel with a test section $1.8 \mathrm{~m}(6 \mathrm{ft})$ high, $2.7 \mathrm{~m} \mathrm{(9 \textrm {ft } )}$ wide and $6.0 \mathrm{~m}(20 \mathrm{ft})$ long. The total air temperature in the test section can be varied between $-30{ }^{\circ} \mathrm{C}$ $\left(-20^{\circ} \mathrm{F}\right)$ and $1{ }^{\circ} \mathrm{C}\left(33^{\circ} \mathrm{F}\right)$ within $\pm 0.5^{\circ} \mathrm{C}\left( \pm 1^{\circ} \mathrm{F}\right)$. Velocities up to $160 \mathrm{~m} / \mathrm{s}$ (350 mph) can be obtained with a blockage of 5 percent in the test section. A spray system allows control of the liquid water content (LWC) between 0.2 to $3.0 \mathrm{~g} / \mathrm{m}^{3}$. The spray nozzles provide droplet median volume diameters (MVD) from 15 to $40 \mu \mathrm{m}$.

\section{B. Model}

The model used in this study was an aluminum NACA 0012 swept wing tip (fig. 1). The airfoil has a $0.381 \mathrm{~m}$ (15 in.) chord measured normal to the leading edge, and a $0.609 \mathrm{~m}$ (24 in.) span. It is mounted in 
the tunnel on a stand that allows pivoting of the airfoil to sweep angles of $0^{\circ}$ to $45^{\circ}$ at $5^{\circ}$ increments. For sweep angles larger than $30^{\circ}$ an extension was fitted at the base of the airfoil to improve the airflow. A grid was painted on the surface of the airfoil to allow identification of the flow direction on the photographic data and to serve as a distance scale in some pictures. A non-activated heater used for previous experiments was left for the first runs of the experiment to determine if there was an effect on the formation of the ice.

\section{Model Position in the Test Section}

Two different positions or configurations of the model in the test section were used in the experiment. One of the configurations was dictated by the need to have the model close to the ceiling of the tunnel to facilitate the close-up photography by reducing the distance between the area of observation and the camera.

The first configuration (Configuration-A, figs. 1 and 2) was the standard position of the model in the test section. In this position the model was sitting on a table bolted to the floor of the tunnel and the area of observation on the airfoil was a distance of $40 \mathrm{in}$. from the ceiling of the tunnel.

In the second configuration (Configuration-B, fig. 3) the model was raised from the floor (on a table) to a height such that the when the model was set at $0^{\circ}$ sweep angle, the closest distance from the airfoil to the ceiling of the tunnel was $1 \mathrm{in}$. In this position, when the model was set at $45^{\circ}$ sweep angle, the area of observation on the airfoil was a distance of $15 \mathrm{in}$. from the ceiling of the tunnel.

\section{Test Matrix}

Tables 1 and 2 list the test matrix for the icing runs. The tables include the run number, the type of airfoil used, the position of the airfoil in the test section and the icing conditions.

Table 1 shows the test conditions used for the appendix $\mathrm{C}$ icing conditions tunnel entry. The Aluminum NACA 0012 Swept Wing Tip airfoil was used for this part of the experiments. The airfoil was set at Configuration- $\mathrm{B}$ in the test section of the tunnel. Two icing conditions were used: Condition $1: \mathrm{V}=$ $150 \mathrm{mph}, \mathrm{T}_{\text {total }}=25^{\circ} \mathrm{F}, \mathrm{LWC}=0.75 \mathrm{~g} / \mathrm{m}^{3}, \mathrm{MVD}=20 \mu \mathrm{m}$ and Condition $2: \mathrm{V}=225 \mathrm{mph}, \mathrm{T}_{\text {total }}=25^{\circ} \mathrm{F}$, $\mathrm{LWC}=0.553 \mathrm{~g} / \mathrm{m}^{3}, \mathrm{MVD}=15.1 \mu \mathrm{m}$. The sweep angle was set at $45^{\circ}$ for nearly all the runs. The main parameter varied was the ice accretion time. Most runs were conducted at ice accretions times between 5 and $60 \mathrm{sec}$ at 5 or $10 \mathrm{sec}$ increments. A limited number of runs were conducted at larger ice accretions times. Digital or film time sequence close-up photography was taken during each run. High resolution close-up photographic data was taken of the ice accretion at the end of each run.

Table 2 shows the test conditions for the SLD tunnel entries. The Aluminum NACA 0012 Swept Wing Tip airfoil was used. The experiment was conducted with the airfoil placed in the test section at Configuration-A. In this configuration the airfoil was set at $45^{\circ}$ sweep angle and a SLD icing condition was used: $\mathrm{V}=172.7 \mathrm{mph}, \mathrm{T}_{\text {total }}=10^{\circ} \mathrm{F}, \mathrm{LWC}=0.75 \mathrm{~g} / \mathrm{m}^{3}, \mathrm{MVD}=200 \mu \mathrm{m}$. Runs were conducted at ice accretion times of 10, 15, 20, 30, 40, 50, 60, 70, 80, and 90 sec. Time sequence close-up photographic data was taken at 3 and/or 5 sec intervals. Close-up high resolution pictures were taken of the ice accretion at the end of each run.

\section{E. Test Procedure}

The photographic system was located on the ceiling of the tunnel. Before each run, the camera focus was set on the area of observation. The system was activated at the start of each run when the tunnel was brought to the target velocity and total temperature and the tunnel spray system was started. During the run the camera took time sequence close-up pictures at 2, 3, and/or 5 sec intervals. A flash system was used for each picture. Most of the photographic data was taken with a digital camera but a $35 \mathrm{~mm}$ camera was used on some runs. Tunnel parameters were recorded using the NASA-Glenn Escort data acquisition 
system. Once the target ice accretion time was reached, the tunnel was brought to idle. After entering the tunnel, a measuring tape was placed around the ice shape, and close-up photographic data (digital and film) was taken following a predetermined sequence and location for the pictures. Then one cut was made in the ice accretion to prepare the ice shape for pencil tracing. A cardboard was placed in the location of the cut and a pencil tracing of the ice shape was made, always at the same location on the airfoil. For the shorter ice accretion times a tracing was not possible due to the small quantity of ice. Following this, general observations on the ice accretion type and formations were recorded. The airfoil was cleaned before the next run.

\section{Results}

\section{A. Photographic Data with Aluminum NACA 0012 Swept Wing Tip in Configuration-B}

The objective of this part of the experiment was to obtain close-up photographic data to observe how roughness elements develop into feathers in the initial stages of the formation of an ice accretion on a swept wing. The runs were conducted with the Aluminum NACA 0012 Swept Wing Tip in Configuration-B. The test matrix is listed in table 1 and was discussed in section II.D. Two kinds of photographic data were obtained: time sequence close-up photographic data during the run and close-up photographic data of the ice accretion at the end of each run.

The time sequence close-up photographic data were taken at 2, 3, 5, 6, and/or 9 sec intervals during each run. Because the airfoil was placed in the tunnel closer to the ceiling (Configuration-B), the distance to the camera was shorter and a larger magnification was possible. As the magnification is increased, the vibration of the airfoil becomes the main limitation to the quality of the data. Although each picture of a sequence is taken separately and potentially the vibration problem can be limited with high shutter speeds, the photographic setup used could not handle shutter speeds shorter than 1/125 sec. This limitation translated into having some of the pictures in each run out of focus (blurred), but enough information could be obtained to determine the time formation of the ice accretion.

The close-up photographic data at the end of each run provided high resolution quality data on how the roughness elements develop into feathers. Separate runs were conducted at 5, 10, 15, 20, 25, 30, 40, $50,60,70,80,90,120,150$, and $180 \mathrm{sec}$. At the end of each run the close-up photographic data were taken in a pre-determined sequence and orientation of the camera with respect to the ice surface. During the first part of the experiment the pictures were taken perpendicular to the ice accretion. It was determined that this did not provide enough information on the 3D shape of the surface features. During the second part of the experiment pictures were taken at a grazing angle to the surface of the ice. It was found that this approach allowed better observation of the 3D features on the ice surface.

\section{Observations from Close-up Photographic Data at the End of Each Run}

The photographic data at the end of each run provided initial clues on how the roughness elements develop into feathers. After a run of $10 \mathrm{sec}$, large droplets can be observed on the ice accretion (fig. 4). The size of the droplets is of the order of $0.3 \mathrm{~mm}$. The droplets are aligned following what looks like bright lines on the picture. For a run of $20 \mathrm{sec}$, the ice accretion shows roughness elements also aligned in a pattern following the bright lines (fig. 5). The bright lines can now be identified as ridges that are forcing the droplets into a pattern. Pictures from a grazing angle confirm the presence of the ridges (figs. 6 and 7). After $30 \mathrm{sec}$ the ridges can be observed more clearly, they exhibit a pointed shape (fig. 8). At 40 sec some droplets can still be observed between the ridges (fig. 9). A close-up of the ice accretion clearly shows the ridges and their shapes (fig. 10). Each ridge presents an upstream facet. At 50 and 60 sec some droplets can still be observed on the surface (fig. 11) but the main feature of the ice accretion in the attachment line area are the ridges (figs. 12 and 13). At 70 sec the following mechanism is observed: the front facet of the ridges grows away from the surface to form the feathers observed along the attachment line area (figs. 14 and 15). At later times of 80, 90, 120, 150 sec the front facet of the 
ridges keep growing away from the icing surface and the feathers that they form are larger (figs. 16, 17, and 18). The growth of the front facet of the ridges away from the surface formed the stem of the feathers and the top of the feathers. The large feathers form the initial scallop tips (fig. 19).

\section{Observations from Time-Sequence Close-Up Photographic Data}

Despite limitations due to blur in some of the frames, the close-up time-sequence photographic data when assembled in a QuickTime movie provided additional information on the overall development of the ice accretions that complemented the information obtained from photographic data at the end of each run. For an icing condition of $\Lambda=45^{\circ}, \mathrm{V}=150 \mathrm{mph}, \mathrm{T}_{\text {total }}=25^{\circ} \mathrm{F}, \mathrm{LWC}=0.75 \mathrm{~g} / \mathrm{m}^{3}, \mathrm{MVD}=20 \mu \mathrm{m}$, the movies made for ice accretion times of $10,20,30,40,50$, and 60 sec showed initial water movement on the surface and the presence of droplets on the leading edge surface at 3 sec into the ice accretion (fig. 20). After the water stops moving, the ice accretion becomes covered with roughness elements at 6 sec into the ice accretion (fig. 21). The roughness elements are observed for some time and then faint lines indicating the presence of ridges can be seen about $18 \mathrm{sec}$ into the ice accretion, becoming more visible at about 21 sec into the ice accretion (fig. 22).

For an icing condition of $\Lambda=30^{\circ}, \mathrm{V}=225 \mathrm{mph}, \mathrm{T}_{\text {total }}=25^{\circ} \mathrm{F}, \mathrm{LWC}=0.553 \mathrm{~g} / \mathrm{m}^{3}, \mathrm{MVD}=15.1 \mu \mathrm{m}$, at an ice accretion time of 3 min a movie showed the change of a roughness element (large droplet) into a pointed-shape through the following sequence:

- A large hemispherical roughness element (droplet) is on the surface (fig. 23)

- The roughness element begins changing to a pointed shape (fig. 24)

- The roughness element develops a pointed shape (fig. 25)

- The roughness element with a pointed shape continues to grow (fig. 26)

The sequence of figures 23 to 26 was obtained in the following way: from the frame by frame images of the movie, the area where the development of the roughness elements occurs was cropped and the sequence of cropped images correspond to figures 23, 24, 25, and 26. There was no reference scale on the movie sequence but the cropped sequence was located on the attachment line zone in the case of an incomplete scallop and from still pictures of the ice accretion taken for a previous run at the same conditions, the area observed in the cropped pictures can be estimated as of the order of $8 \mathrm{~mm}$ in the vertical direction.

\section{B. Photographic Data at SLD Condition with Aluminum NACA 0012 Swept Wing Tip in Configuration-A}

In this part of the experiment observations were conducted at a SLD condition of $\Lambda=45^{\circ}$, $\mathrm{V}=172.7 \mathrm{mph}, \mathrm{T}_{\text {total }}=10^{\circ} \mathrm{F}, \mathrm{LWC}=0.75 \mathrm{~g} / \mathrm{m}^{3}, \mathrm{MVD}=200 \mu \mathrm{m}$. The test matrix is listed in table 2 and was discussed in section II.D. At this condition the ice accretion was observed to be a complete scallop. Photographic data at the end of the run for short times from 10 to 90 sec confirmed the observations done previously at appendix $\mathrm{C}$ icing conditions with the added benefit that the process develops more slowly and is more easily observable. The formation of ridges and the change of the ridges into feathers and scallop tips were confirmed and clearly observed. The following was the sequence observed:

1) After $10 \mathrm{sec}$ ridges are already forming on the ice accretion (fig. 27). The ridges are made of large roughness elements that are joining others on their side (fig. 28). Some individual elements can be observed. Figure 29 shows the ridges seen from a grazing angle in the direction of the flow.

2) After $15 \mathrm{sec}$ the ridges are formed on the ice accretion. An overall view of the ice accretion shows the pattern that they form (fig. 30). A closer view shows that they are still small but well defined (fig. 31). Their origin from roughness elements joining on their sides can still be seen. A 
side view shows the pointed shape of the ridges with an upstream facet (fig. 32). A grazing angle along the attachment line, from below, in the direction of the flow, shows a direct view of the ridges and their front facet (fig. 33).

3) After $20 \mathrm{sec}$ the ridges are now larger and the front facet can be seen clearly (fig. 34).

4) After $30 \mathrm{sec}$ the ridges are larger (fig. 35) and the front facet is starting to grow away from the surface forming large feathers (fig. 36).

5) After $40 \mathrm{sec}$ the front facet of the ridges continues growing away. Figure 37 shows a close-up of the front facet of the ridges when seen from below along the attachment line in the direction of the flow. A grazing angle view from upstream, looking into the flow, shows the back side of the ridges (fig. 38).

6) After $50 \mathrm{sec}$ the front facets of the ridges have grown away from the surface forming large feathers and scallop tips (figs. 39 and 40).

7) After 60, 70, 80, and 90 sec the growth of the front facet of the ridges away from the surface continues and the feathers formed by the ridges grow larger and form well defined scallop tips (figs. 41 and 42). A grazing view looking from upstream into the flow shows the back side of the ridges with their teeth-like structure (fig. 43).

8) After $10 \mathrm{~min}$ (fig. 44) the ice accretion is a complete scallop with well developed scallop tips that formed from the original ridges.

The observations allow to identify the steps that lead from roughness elements to ridges, to feathers formed when the front facet of the ridges grows away from the surface, to the scallop tips that the feathers form.

\section{Discussion}

The results presented in section III provide a qualitative view of how individual feathers form, how roughness elements form ridges and how the front facet of the ridges grows away from the surface to form feathers and the initial scallop tips of the ice accretion. The results provide new information in two main areas: (1) In a complete scallop roughness elements develop into ridges and the ridges into the glaze feathers that cover the ice shape and form the initial scallop tips; (2) A mechanism of how individual glaze ice feathers form.

\section{From Roughness Elements to Ridges and from Ridges to Feathers in the Formation of a Complete Scallop}

The observations uncovered three previously unknown processes in the formation of the feathers and initial scallop tips in the complete scallop case:

- Roughness elements in the initial stages of the ice accretion formation change into a pointed shape that has a front facet facing the flow direction.

- Groups of roughness elements that have changed to the pointed shape join on their side to form ridges. The ridges formed also have a front facet facing the flow direction.

- The front facet of the ridges grows away from the surface. This mechanism creates the feathers because the growth of the facet away from the surface creates the stems of the feathers and their tops. As the front facet keeps growing away the feathers become bigger and form the initial scallop tips.

These steps in the formation of feathers on complete scallops will have to be considered in the modeling of ice accretion formation on swept wings because they provide the process by which roughness elements form glaze ice feathers in a complete scallop. The results have strong implications for the type of experiments and computer simulations that need to be developed to obtain the data needed for modeling. Experiments will have to be developed to determine if the change of shape of the roughness 
elements is related to heat transfer and flow field. Additional research will be needed to determine why and under what conditions the front facets of the ridges grow away from the surface to form the feathers. This is critical because it will allow prediction of when feathers form and of the critical distance, the key parameter in scallop formation. More studies are needed to determine if the angle of growth of glaze ice feathers is related to the change into the pointed shape.

One aspect of the process that needs to be further investigated is how early the ridges form and how their formation depends on icing conditions. From the photographic data it is very hard to determine exactly when they first appear on the ice accretion. In the experimental results presented in this report the ridges were already observed on the ice accretion at 10 to 20 sec into the icing encounter. The image resolution of the movies did not allow to determine if they were present or not at an earlier time. Higher resolution close-up movies of the ice accretion formation will be needed to determine how early they appear for a given icing condition.

\section{Formation of Individual Glaze Ice Feathers}

From the observations a mechanism of glaze feather formation can be inferred: a hemispherical shaped roughness element forms on the surface of the ice accretion; the roughness element on the ice accretion freezes in a pointed shape with a facet at an angle in the upstream side; the front facet grows outwards creating the actual feather, in this case an individual feather.

The following is a $2 \mathrm{D}$ drawing illustrating the observed dynamics of single glaze feather formation:

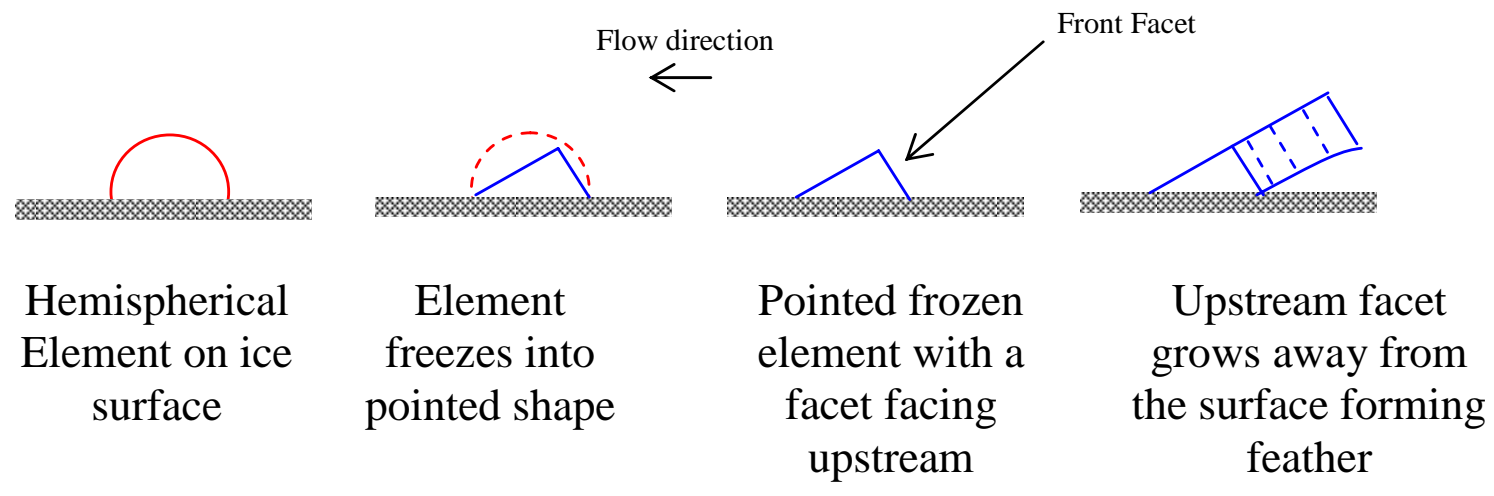

2-D drawing illustrating the observed dynamics of single glaze feather formation.

A feather is a 3D structure that has three directions of growth, in the 2D drawing above only one direction of growth is being shown, the dominant direction of growth for a feather.

It should be made clear that the mechanism observed is for feathers forming at glaze ice conditions during a complete scallop formation in the area of the main ice accretion. As shown in figure 45, in a glaze ice situation feathers can grow as part of the main ice accretion or away from the main ice accretion as separate individual feathers. The mechanism of growth for individual feathers forming away from the main ice accretion or for feathers growing on indentations or by deposition on the surface of the airfoil was not studied in the experiment presented in this report. It remains for further studies to determine if the mechanism of growth presented here applies to those feathers or if they grow by a different one.

\section{Summary and Final Comments}

An experiment was conducted in the Icing Research Tunnel at NASA Glenn Research Center to answer the following research question: what is the actual process by which roughness elements develop into feathers and form scallop tips in the initial stages of the ice accretion formation on a swept airfoil? The results showed that roughness elements changed to a pointed shape with an upstream facet. Groups of 
roughness elements that have changed to the pointed shape join on their side to form ridges that also exhibit a front facet facing the flow direction. The front facet of the ridges grows away from the surface to form the large feathers observed and scallop tips observed in complete scallop ice shapes. This is the first time that the dynamics of glaze ice feather and scallop tip initiation has been observed.

The objective of the icing physics studies on swept wings is to provide information for the modeling of ice accretion formation and to provide guidance on the experiments that need to be conducted to obtain the data needed for modeling. The observations presented above provide new information on the steps that occur in the formation of glaze ice feathers during the formation of a complete scallop. Those steps need to be considered in the development of the experiments, computational simulations and mathematical models needed to predict the formation of ice accretions on a swept wing. The observations also raise new questions that need to be answered in future icing physics experiments.

\section{References}

1. Vargas, M., “Current Experimental Basis for Modeling Ice Accretions on Swept Wings,” AIAA Paper 2005-5188, June 2005.

2. Vargas, M., "Ice Accretion on Swept Wings at Glaze Ice Conditions,” Ph.D. Thesis, Case Western Reserve University, Cleveland, Ohio, May 1998.

3. Vargas, M. and Reshotko, E., "Physical Mechanisms of Glaze Ice Scallop Formations on Swept Wings,” AIAA Paper 98-0491 and NASA TM-1998-206616, Jan. 1998.

4. Vargas, M. and Reshotko, E., "Parametric Experimental Study of the Formation of Glaze Ice Shapes on Swept Wings,” AIAA Paper 99-0094, Jan. 1999.

5. Vargas, M. and Reshotko, E., "LWC and Temperature Effects on Ice Accretion Formation on Swept Wings at Glaze Ice Conditions,” AIAA Paper 2000-00483, Jan. 2000.

6. Vargas, M., Giriunas, J. and Ratvasky, T., "Ice Accretion Formations on a NACA 0012 Swept Wing Tip in Natural Icing Conditions,” AIAA Paper 2002-0244, Jan. 2002. 
TABLE 1.-TEST CONDITIONS FOR ALUMINUM NACA 0012 SWEPT WING TIP AIRFOIL IN CONFIGURATION-B

\begin{tabular}{|c|c|c|c|c|c|c|c|c|}
\hline $\begin{array}{c}\text { Run } \\
\text { number }\end{array}$ & Airfoil & $\begin{array}{l}\text { Airfoil position } \\
\text { in the test section }\end{array}$ & $\begin{array}{l}\text { Sweep } \\
\text { angle }\end{array}$ & $\begin{array}{l}\text { Velocity, } \\
\text { (mph) }\end{array}$ & $\begin{array}{c}\text { Total } \\
\text { temperature, } \\
\left({ }^{\circ} \mathrm{F}\right)\end{array}$ & $\begin{array}{l}\text { LWC, } \\
\left(\mathrm{g} / \mathrm{m}^{3}\right)\end{array}$ & $\begin{array}{c}\text { MVD, } \\
(\mu \mathrm{m})\end{array}$ & $\begin{array}{c}\text { Ice } \\
\text { accretion } \\
\text { time, } \\
\text { (min) } \\
\end{array}$ \\
\hline 030806.01 & Al-NACA 0012 & Configuration-B & 45 & 150 & 22 & 0.75 & 20 & $2 \min$ \\
\hline 030806.02 & Al-NACA 0012 & Configuration-B & 45 & 150 & 25 & 0.75 & 20 & $2 \min$ \\
\hline 030806.03 & Al-NACA 0012 & Configuration-B & 45 & 150 & 25 & 0.75 & 20 & $2 \mathrm{~min}$ \\
\hline 030806.04 & Al-NACA 0012 & Configuration-B & 45 & 150 & 25 & 0.75 & 20 & $5 \mathrm{sec}$ \\
\hline 030806.05 & Al-NACA 0012 & Configuration-B & 45 & 150 & 25 & 0.75 & 20 & $10 \mathrm{sec}$ \\
\hline 030806.06 & Al-NACA 0012 & Configuration-B & 45 & 150 & 25 & 0.75 & 20 & $15 \mathrm{sec}$ \\
\hline 030806.07 & Al-NACA 0012 & Configuration-B & 45 & 150 & 25 & 0.75 & 20 & $15 \mathrm{sec}$ \\
\hline 030806.08 & Al-NACA 0012 & Configuration-B & 45 & 150 & 25 & 0.75 & 20 & $20 \mathrm{sec}$ \\
\hline 030806.09 & Al-NACA 0012 & Configuration-B & 45 & 150 & 25 & 0.75 & 20 & $25 \mathrm{sec}$ \\
\hline 030806.10 & Al-NACA 0012 & Configuration-B & 45 & 150 & 25 & 0.75 & 20 & $30 \mathrm{sec}$ \\
\hline 030806.11 & Al-NACA 0012 & Configuration-B & 45 & 150 & 25 & 0.75 & 20 & $35 \mathrm{sec}$ \\
\hline 030806.12 & Al-NACA 0012 & Configuration-B & 45 & 150 & 25 & 0.75 & 20 & $40 \mathrm{sec}$ \\
\hline 030906.01 & Al-NACA 0012 & Configuration-B & 45 & 150 & 25 & 0.75 & 20 & $3 \mathrm{sec}$ \\
\hline 030906.02 & Al-NACA 0012 & Configuration-B & 45 & 150 & 25 & 0.75 & 20 & $45 \mathrm{sec}$ \\
\hline 030906.03 & Al-NACA 0012 & Configuration-B & 45 & 150 & 25 & 0.75 & 20 & $50 \mathrm{sec}$ \\
\hline 030906.04 & Al-NACA 0012 & Configuration-B & 45 & 150 & 25 & 0.75 & 20 & $55 \mathrm{sec}$ \\
\hline 030906.05 & Al-NACA 0012 & Configuration-B & 45 & 150 & 25 & 0.75 & 20 & $55 \mathrm{sec}$ \\
\hline 030906.06 & Al-NACA 0012 & Configuration-B & 45 & 150 & 25 & 0.75 & 20 & $60 \mathrm{sec}$ \\
\hline 030906.07 & Al-NACA 0012 & Configuration-B & 45 & 150 & 25 & 0.75 & 20 & $2 \mathrm{~min}$ \\
\hline 030906.08 & Al-NACA 0012 & Configuration-B & 45 & 150 & 25 & 0.75 & 20 & $2 \mathrm{~min}$ \\
\hline 030906.09 & Al-NACA 0012 & Configuration-B & 45 & 150 & 25 & 0.75 & 20 & $70 \mathrm{sec}$ \\
\hline 030906.10 & Al-NACA 0012 & Configuration-B & 45 & 150 & 25 & 0.75 & 20 & $80 \mathrm{sec}$ \\
\hline 030906.11 & Al-NACA 0012 & Configuration-B & 45 & 150 & 25 & 0.75 & 20 & $90 \mathrm{sec}$ \\
\hline 030906.12 & Al-NACA 0012 & Configuration-B & 45 & 150 & 25 & 0.75 & 20 & $120 \mathrm{sec}$ \\
\hline 030906.13 & Al-NACA 0012 & Configuration-B & 45 & 150 & 25 & 0.75 & 20 & $150 \mathrm{sec}$ \\
\hline 031006.01 & Al-NACA 0012 & Configuration-B & 45 & 150 & 25 & 0.75 & 20 & $180 \mathrm{sec}$ \\
\hline 031006.02 & Al-NACA 0012 & Configuration-B & 45 & 225 & 25 & 0.553 & 15.1 & $3 \mathrm{~min}$ \\
\hline 031006.03 & Al-NACA 0012 & Configuration-B & 45 & 225 & 25 & 0.553 & 15.1 & $3 \mathrm{~min}$ \\
\hline 031006.04 & Al-NACA 0012 & Configuration-B & 45 & 225 & 25 & 0.553 & 15.1 & $5 \mathrm{sec}$ \\
\hline 031006.05 & Al-NACA 0012 & Configuration-B & 45 & 225 & 25 & 0.553 & 15.1 & $10 \mathrm{sec}$ \\
\hline 031006.06 & Al-NACA 0012 & Configuration-B & 45 & 225 & 25 & 0.553 & 15.1 & $15 \mathrm{sec}$ \\
\hline 031006.07 & Al-NACA 0012 & Configuration-B & 45 & 225 & 25 & 0.553 & 15.1 & $20 \mathrm{sec}$ \\
\hline 031006.08 & Al-NACA 0012 & Configuration-B & 45 & 225 & 25 & 0.553 & 15.1 & $25 \mathrm{sec}$ \\
\hline 031006.09 & Al-NACA 0012 & Configuration-B & 45 & 225 & 25 & 0.553 & 15.1 & $30 \mathrm{sec}$ \\
\hline 031006.10 & Al-NACA 0012 & Configuration-B & 45 & 225 & 25 & 0.553 & 15.1 & $5 \mathrm{sec}$ \\
\hline 031006.11 & Al-NACA 0012 & Configuration-B & 45 & 225 & 25 & 0.553 & 15.1 & $10 \mathrm{sec}$ \\
\hline
\end{tabular}


TABLE 1.-Concluded.

\begin{tabular}{|c|c|c|c|c|c|c|c|c|}
\hline $\begin{array}{c}\text { Run } \\
\text { number }\end{array}$ & Airfoil & $\begin{array}{l}\text { Airfoil position } \\
\text { in the test section }\end{array}$ & $\begin{array}{l}\text { Sweep } \\
\text { angle }\end{array}$ & $\begin{array}{l}\text { Velocity, } \\
\text { (mph) }\end{array}$ & $\begin{array}{c}\text { Total } \\
\text { temperature, } \\
\left({ }^{\circ} \mathrm{F}\right)\end{array}$ & $\begin{array}{l}\text { LWC, } \\
\left(\mathrm{g} / \mathrm{m}^{3}\right)\end{array}$ & $\begin{array}{l}\text { MVD, } \\
(\mu \mathrm{m})\end{array}$ & $\begin{array}{c}\text { Ice } \\
\text { accretion } \\
\text { time, } \\
\text { (min) } \\
\end{array}$ \\
\hline 031306.01 & Al-NACA 0012 & Configuration-B & 30 & 225 & 25 & 0.553 & 15.1 & $3 \mathrm{~min}$ \\
\hline 031306.02 & Al-NACA 0012 & Configuration-B & 30 & 225 & 25 & 0.553 & 15.1 & $3 \mathrm{~min}$ \\
\hline 031306.03 & Al-NACA 0012 & Configuration-B & 45 & 225 & 25 & 0.553 & 15.1 & $3 \min$ \\
\hline 031306.04 & Al-NACA 0012 & Configuration-B & 45 & 225 & 25 & 0.553 & 15.1 & $5 \mathrm{sec}$ \\
\hline 031306.05 & Al-NACA 0012 & Configuration-B & 45 & 225 & 25 & 0.553 & 15.1 & $10 \mathrm{sec}$ \\
\hline 031306.06 & Al-NACA 0012 & Configuration-B & 45 & 225 & 25 & 0.553 & 15.1 & $15 \mathrm{sec}$ \\
\hline 031306.07 & Al-NACA 0012 & Configuration-B & 45 & 225 & 25 & 0.553 & 15.1 & $10 \mathrm{sec}$ \\
\hline 031306.08 & Al-NACA 0012 & Configuration-B & 45 & 225 & 25 & 0.553 & 15.1 & $20 \mathrm{sec}$ \\
\hline 031306.09 & Al-NACA 0012 & Configuration-B & 45 & 225 & 25 & 0.553 & 15.1 & $25 \mathrm{sec}$ \\
\hline 031406.01 & Al-NACA 0012 & Configuration-B & 45 & 225 & 25 & 0.553 & 15.1 & $30 \mathrm{sec}$ \\
\hline 031406.02 & Al-NACA 0012 & Configuration-B & 45 & 150 & 25 & 0.75 & 20 & $10 \mathrm{sec}$ \\
\hline 031406.03 & Al-NACA 0012 & Configuration-B & 45 & 150 & 25 & 0.75 & 20 & $20 \mathrm{sec}$ \\
\hline 031406.04 & Al-NACA 0012 & Configuration-B & 45 & 150 & 25 & 0.75 & 20 & $30 \mathrm{sec}$ \\
\hline 031406.05 & Al-NACA 0012 & Configuration-B & 45 & 150 & 25 & 0.75 & 20 & $40 \mathrm{sec}$ \\
\hline 031406.06 & Al-NACA 0012 & Configuration-B & 45 & 150 & 25 & 0.75 & 20 & $50 \mathrm{sec}$ \\
\hline 031406.07 & Al-NACA 0012 & Configuration-B & 45 & 150 & 25 & 0.75 & 20 & $60 \mathrm{sec}$ \\
\hline 031406.08 & Al-NACA 0012 & Configuration-B & 45 & 225 & 25 & 0.553 & 15.1 & $3 \mathrm{~min}$ \\
\hline 031406.09 & Al-NACA 0012 & Configuration-B & 45 & 225 & 25 & 0.553 & 15.1 & $3 \min$ \\
\hline 031406.10 & Al-NACA 0012 & Configuration-B & 45 & 225 & 25 & 0.553 & 15.1 & $5 \mathrm{sec}$ \\
\hline 031406.11 & Al-NACA 0012 & Configuration-B & 45 & 225 & 25 & 0.553 & 15.1 & $10 \mathrm{sec}$ \\
\hline 031406.12 & Al-NACA 0012 & Configuration-B & 45 & 225 & 25 & 0.553 & 15.1 & $15 \mathrm{sec}$ \\
\hline 031406.13 & Al-NACA 0012 & Configuration-B & 45 & 225 & 25 & 0.553 & 15.1 & $20 \mathrm{sec}$ \\
\hline 031406.14 & Al-NACA 0012 & Configuration-B & 45 & 225 & 25 & 0.553 & 15.1 & $25 \mathrm{sec}$ \\
\hline 031406.15 & Al-NACA 0012 & Configuration-B & 45 & 225 & 25 & 0.553 & 15.1 & $30 \mathrm{sec}$ \\
\hline 031406.16 & Al-NACA 0012 & Configuration-B & 45 & 225 & 25 & 0.553 & 15.1 & $35 \mathrm{sec}$ \\
\hline
\end{tabular}


TABLE 2.-SLD TEST CONDITIONS FOR ALUMINUM NACA 0012 SWEPT WING TIP AIRFOIL IN CONFIGURATION-A

\begin{tabular}{|c|c|c|c|c|c|c|c|c|}
\hline $\begin{array}{c}\text { Run } \\
\text { number }\end{array}$ & Airfoil & $\begin{array}{c}\text { Airfoil position } \\
\text { in the test } \\
\text { section }\end{array}$ & $\begin{array}{c}\text { Sweep } \\
\text { angle }\end{array}$ & $\begin{array}{c}\text { Velocity, } \\
(\mathrm{mph})\end{array}$ & $\begin{array}{c}\text { Total } \\
\text { temperature, } \\
\left({ }^{\circ} \mathrm{F}\right)\end{array}$ & $\begin{array}{c}\text { LWC, } \\
\left(\mathrm{g} / \mathrm{m}^{3}\right)\end{array}$ & $\begin{array}{c}\text { MVD, } \\
(\mu \mathrm{m})\end{array}$ & $\begin{array}{c}\text { Ice } \\
\text { accretion } \\
\text { time, } \\
(\mathrm{min})\end{array}$ \\
\hline 121206.08 & Al-NACA 0012 & Configuration-A & 45 & $172.7(150 \mathrm{kt})$ & 10 & 0.75 & 200 & $10 \mathrm{sec}$ \\
\hline 121206.09 & Al-NACA 0012 & Configuration-A & 45 & $172.7(150 \mathrm{kt})$ & 10 & 0.75 & 200 & $20 \mathrm{sec}$ \\
\hline 121206.10 & Al-NACA 0012 & Configuration-A & 45 & $172.7(150 \mathrm{kt})$ & 10 & 0.75 & 200 & $30 \mathrm{sec}$ \\
\hline 121306.02 & Al-NACA 0012 & Configuration-A & 45 & $172.7(150 \mathrm{kt})$ & 10 & 0.75 & 200 & $30 \mathrm{sec}$ \\
\hline 121306.03 & Al-NACA 0012 & Configuration-A & 45 & $172.7(150 \mathrm{kt})$ & 10 & 0.75 & 200 & $40 \mathrm{sec}$ \\
\hline 121306.04 & Al-NACA 0012 & Configuration-A & 45 & $172.7(150 \mathrm{kt})$ & 10 & 0.75 & 200 & $50 \mathrm{sec}$ \\
\hline 121306.05 & Al-NACA 0012 & Configuration-A & 45 & $172.7(150 \mathrm{kt})$ & 10 & 0.75 & 200 & $60 \mathrm{sec}$ \\
\hline 121306.06 & Al-NACA 0012 & Configuration-A & 45 & $172.7(150 \mathrm{kt})$ & 10 & 0.75 & 200 & $70 \mathrm{sec}$ \\
\hline 121306.07 & Al-NACA 0012 & Configuration-A & 45 & $172.7(150 \mathrm{kt})$ & 10 & 0.75 & 200 & $80 \mathrm{sec}$ \\
\hline 121306.08 & Al-NACA 0012 & Configuration-A & 45 & $172.7(150 \mathrm{kt})$ & 10 & 0.75 & 200 & $90 \mathrm{sec}$ \\
\hline 121306.09 & Al-NACA 0012 & Configuration-A & 45 & $172.7(150 \mathrm{kt})$ & 10 & 0.75 & 200 & $15 \mathrm{sec}$ \\
\hline
\end{tabular}




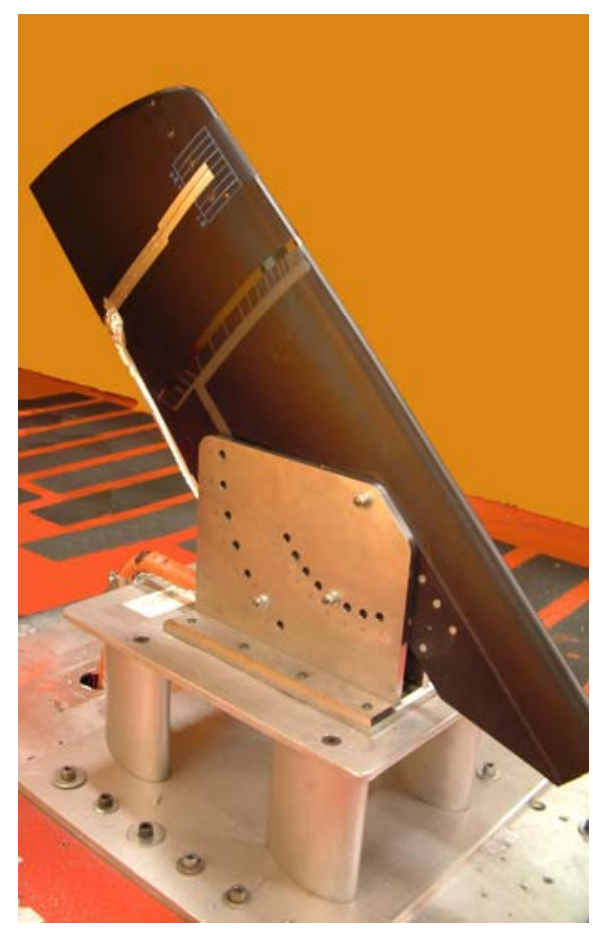

Figure 1.-Aluminum NACA 0012 swept wing tip in the IRT test section.

Configuration-A for the airfoil in the test section of the tunnel.

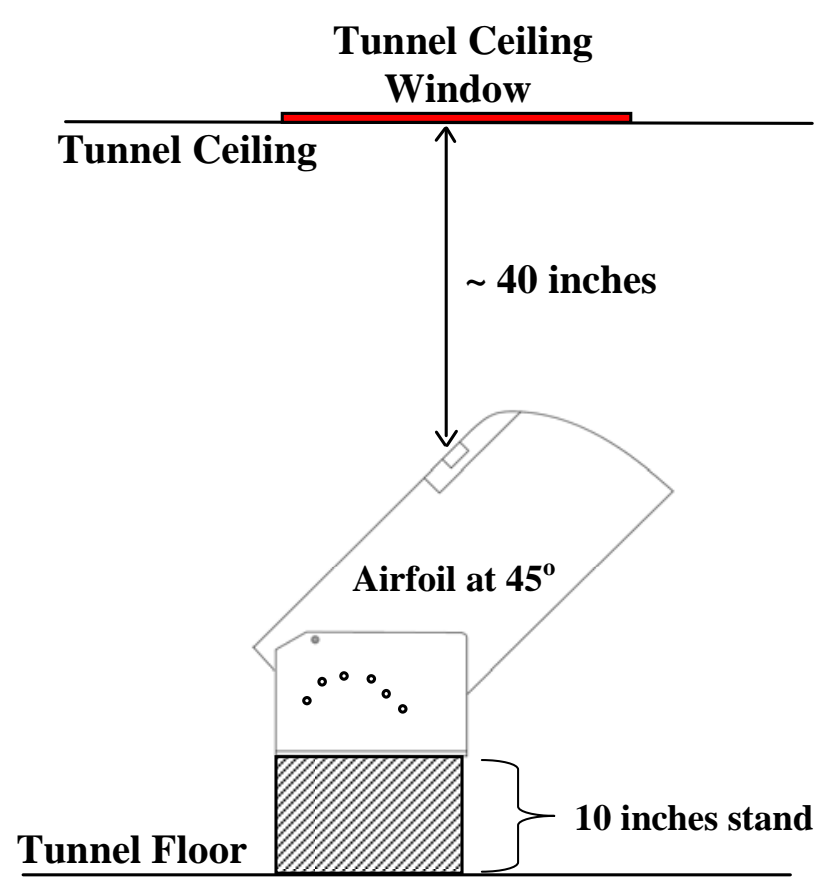

Figure 2.-Drawing of Configuration-A for the airfoil in the test section of the tunnel.

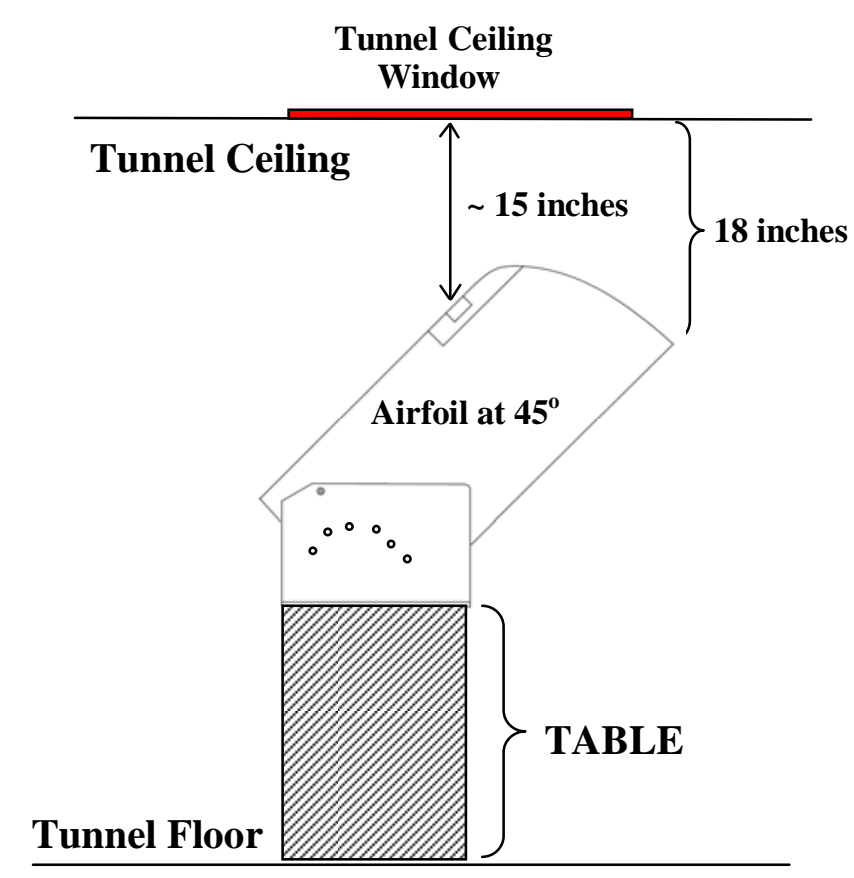

Figure 3.-Drawing of Configuration-B for the airfoil in the test section of the tunnel. 


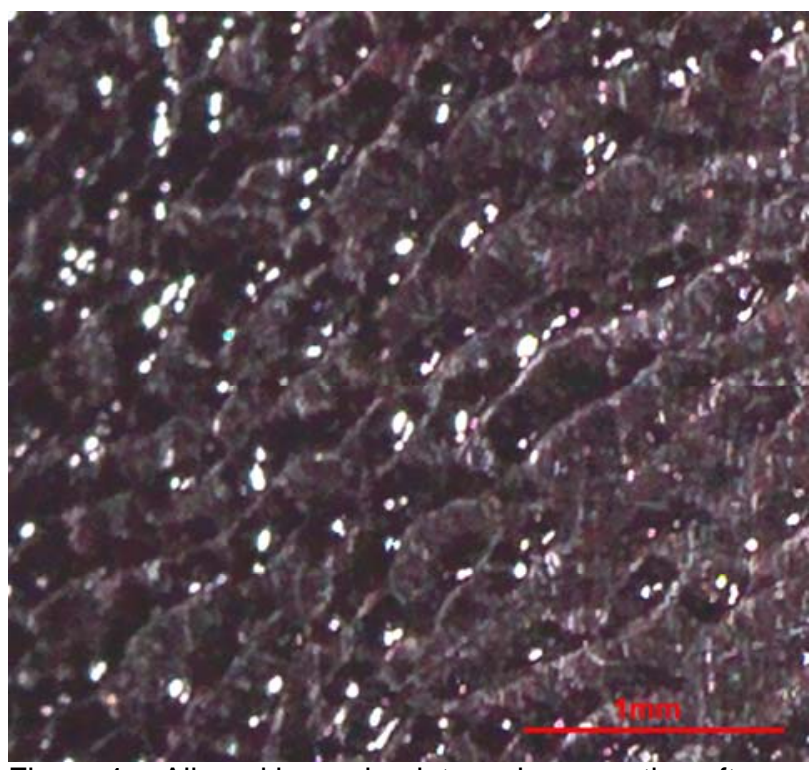

Figure 4.-Aligned large droplets on ice accretion after $10 \mathrm{sec} . \Lambda=45^{\circ}, V=150 \mathrm{mph}, \mathrm{T}_{\text {total }}=25^{\circ} \mathrm{F}, \mathrm{LWC}=$ $0.75 \mathrm{~g} / \mathrm{m}^{3}, \mathrm{MVD}=20 \mu \mathrm{m}, \tau=10 \mathrm{sec}$. Direction of flow is from bottom to top.
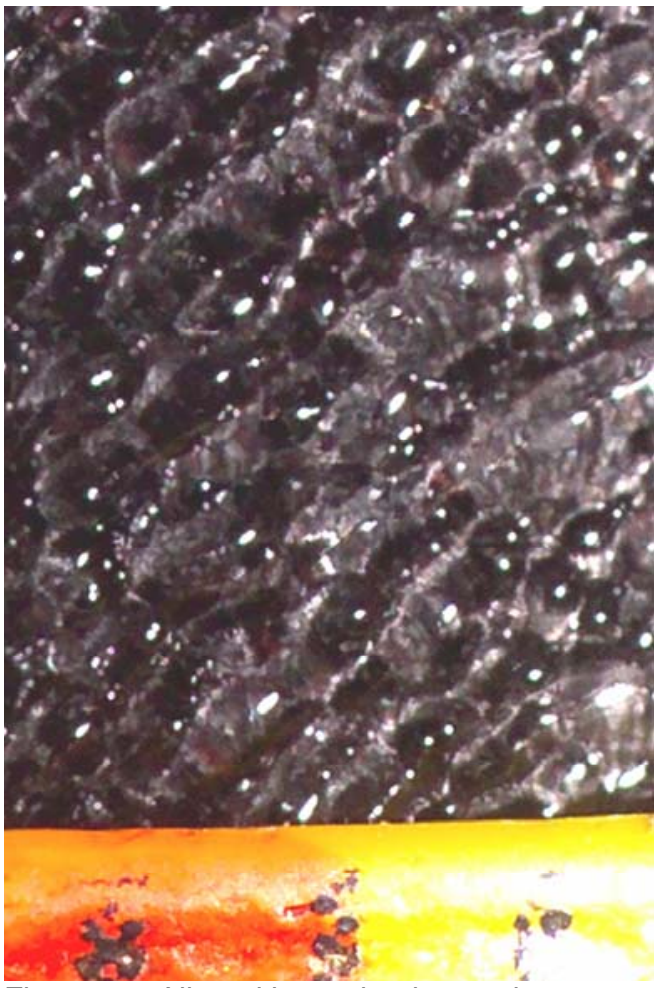

Figure 5.-Aligned large droplets on ice accretion after $20 \mathrm{sec}$. Ridges can be identified. Picture taken perpendicular to the ice accretion. $\Lambda=45^{\circ}, \mathrm{V}=150 \mathrm{mph}, \mathrm{T}_{\text {total }}=$ $25^{\circ} \mathrm{F}, \mathrm{LWC}=0.75 \mathrm{~g} / \mathrm{m}^{3}, \mathrm{MVD}=20 \mu \mathrm{m}$, $\tau=20 \mathrm{sec}$. Direction of flow is from bottom to top. Smallest scale on tape is $1 \mathrm{~mm}$.

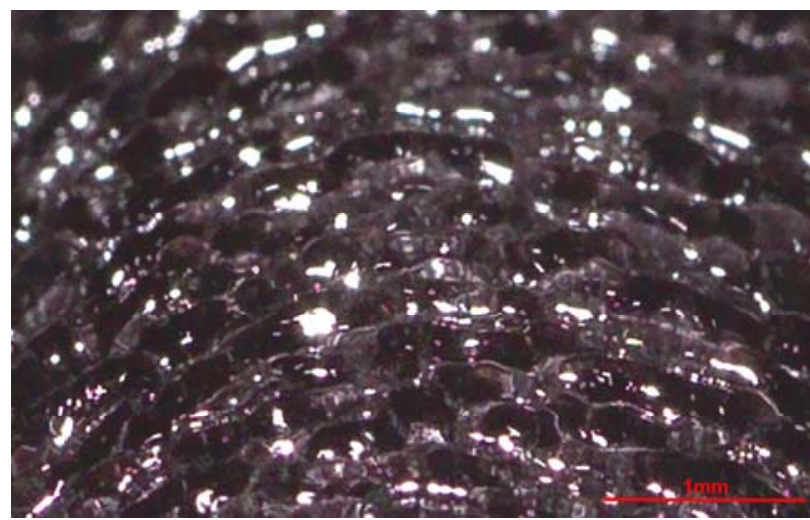

Figure 6.-After $20 \mathrm{sec}$ ridges can be observed. Picture taken at a grazing angle to the ice accretion. $\Lambda=45^{\circ}$, $\mathrm{V}=150 \mathrm{mph}, \mathrm{T}_{\text {total }}=25^{\circ} \mathrm{F}, \mathrm{LWC}=0.75 \mathrm{~g} / \mathrm{m}^{3}, \mathrm{MVD}=$ $20 \mu \mathrm{m}, \tau=20 \mathrm{sec}$. Direction of flow is from bottom to top.

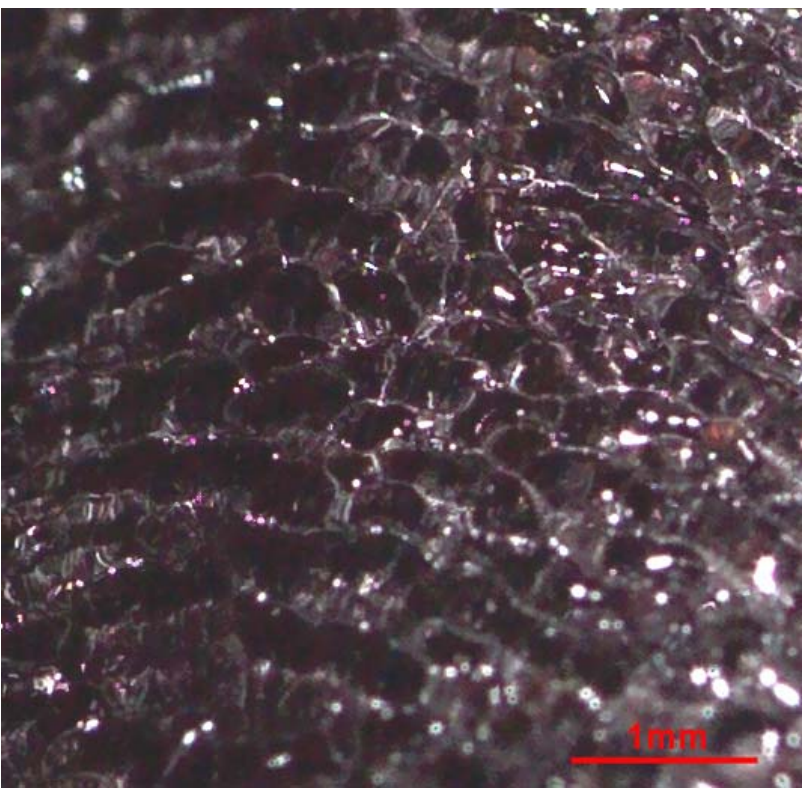

Figure 7.-After $20 \mathrm{sec}$ ridges can be observed. Picture taken at a grazing angle to the ice accretion. $\Lambda=45^{\circ}$, $\mathrm{V}=150 \mathrm{mph}, \mathrm{T}_{\text {total }}=25^{\circ} \mathrm{F}, \mathrm{LWC}=0.75 \mathrm{~g} / \mathrm{m}^{3}$, $M V D=20 \mu \mathrm{m}, \tau=20 \mathrm{sec}$. Direction of flow is from bottom to top. 


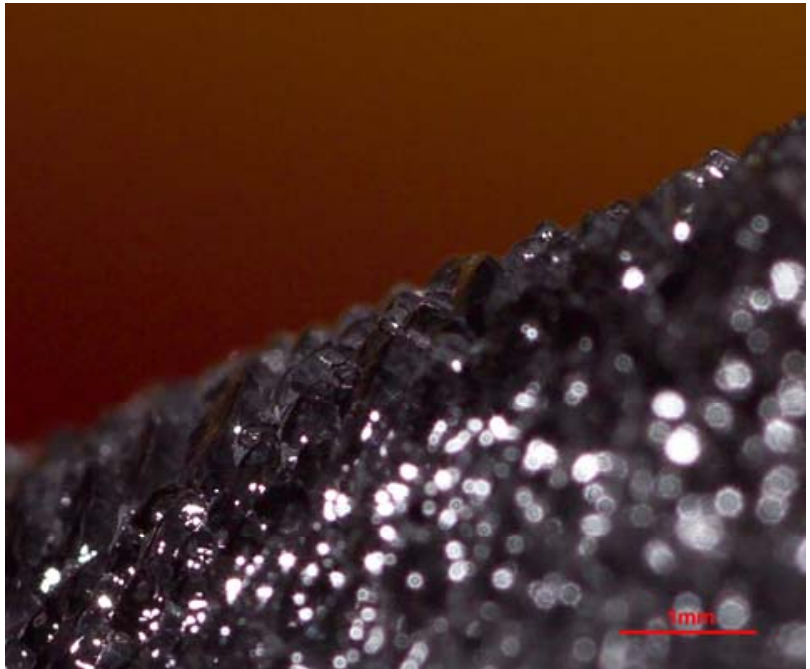

Figure 8.-Aligned large droplets on ice accretion after $30 \mathrm{sec}$, forming ridges with a pointed shape. $\Lambda=45^{\circ}$, $\mathrm{V}=150 \mathrm{mph}, \mathrm{T}_{\text {total }}=25^{\circ} \mathrm{F}, \mathrm{LWC}=0.75 \mathrm{~g} / \mathrm{m}^{3}, \mathrm{MVD}=$ $20 \mu \mathrm{m}, \tau=30 \mathrm{sec}$. Direction of flow is from left to right.

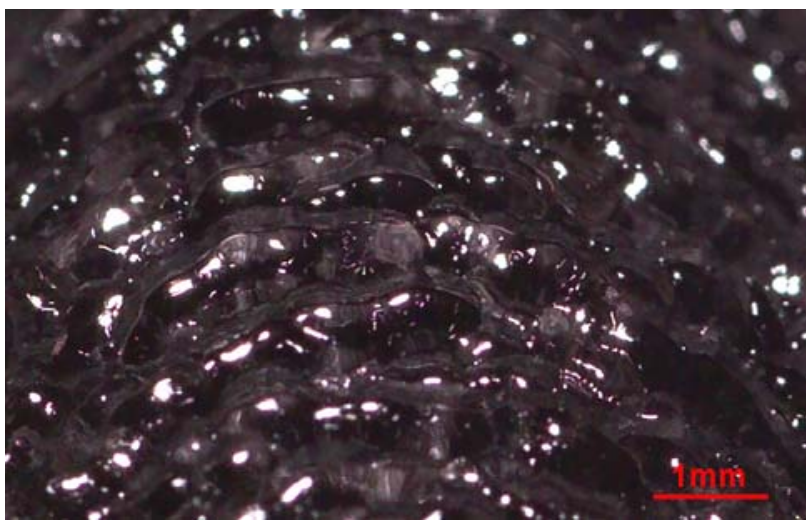

Figure 10.-Large droplets on ice accretion after $40 \mathrm{sec}$, between clearly defined ridges. $\Lambda=45^{\circ}, \mathrm{V}=150 \mathrm{mph}$, $\mathrm{T}_{\text {total }}=25^{\circ} \mathrm{F}, \mathrm{LWC}=0.75 \mathrm{~g} / \mathrm{m}^{3}, \mathrm{MVD}=20 \mu \mathrm{m}, \tau=$ $40 \mathrm{sec}$. Direction of flow is from bottom to top.

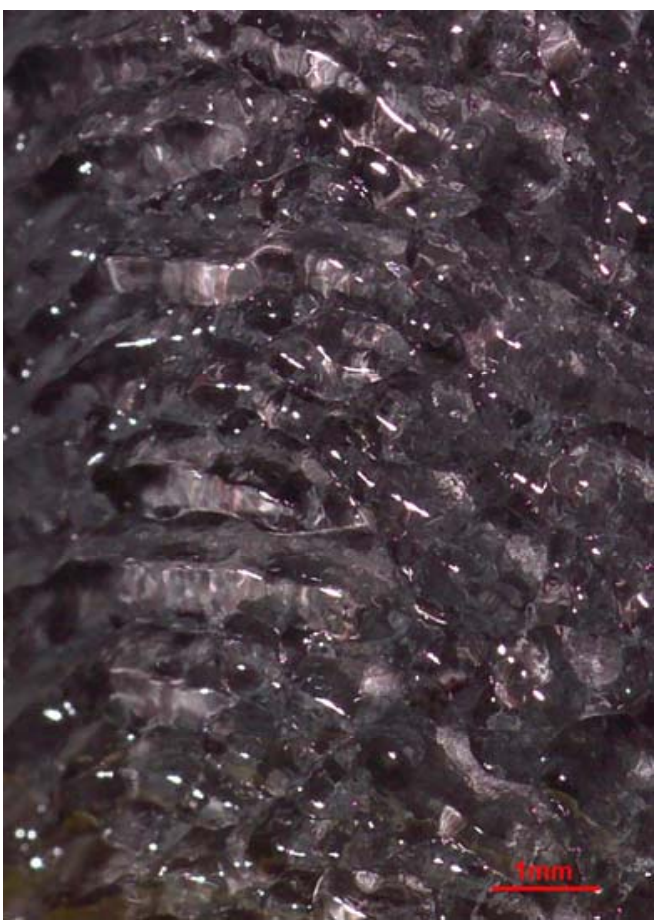

Figure 9.-Large droplets on ice accretion after $40 \mathrm{sec}$, between clearly defined ridges. $\Lambda=45^{\circ}, \mathrm{V}=150 \mathrm{mph}, \mathrm{T}_{\text {total }}=25^{\circ} \mathrm{F}, \mathrm{LWC}=$ $0.75 \mathrm{~g} / \mathrm{m}^{3}, \mathrm{MVD}=20 \mu \mathrm{m}, \tau=40 \mathrm{sec}$.

Direction of flow is from bottom to top.

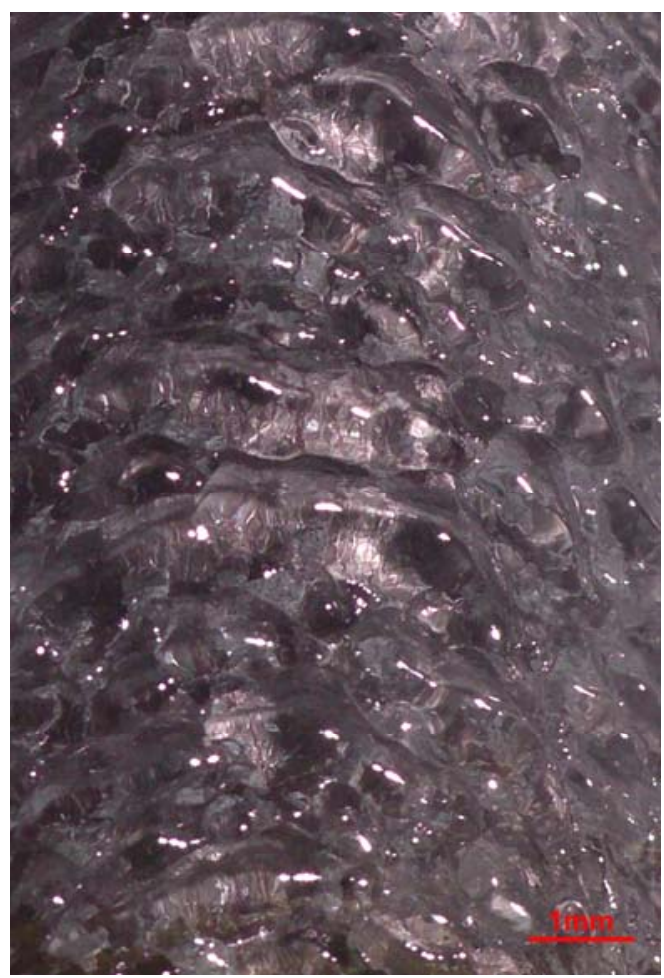

Figure 11._A few droplets and many ridges after 50 sec. $\Lambda=45^{\circ}, \mathrm{V}=150 \mathrm{mph}, \mathrm{T}_{\text {total }}=$ $25^{\circ} \mathrm{F}, \mathrm{LWC}=0.75 \mathrm{~g} / \mathrm{m}^{3}, \mathrm{MVD}=20 \mu \mathrm{m}$, $\tau=50 \mathrm{sec}$. Direction of flow is from bottom to top. 


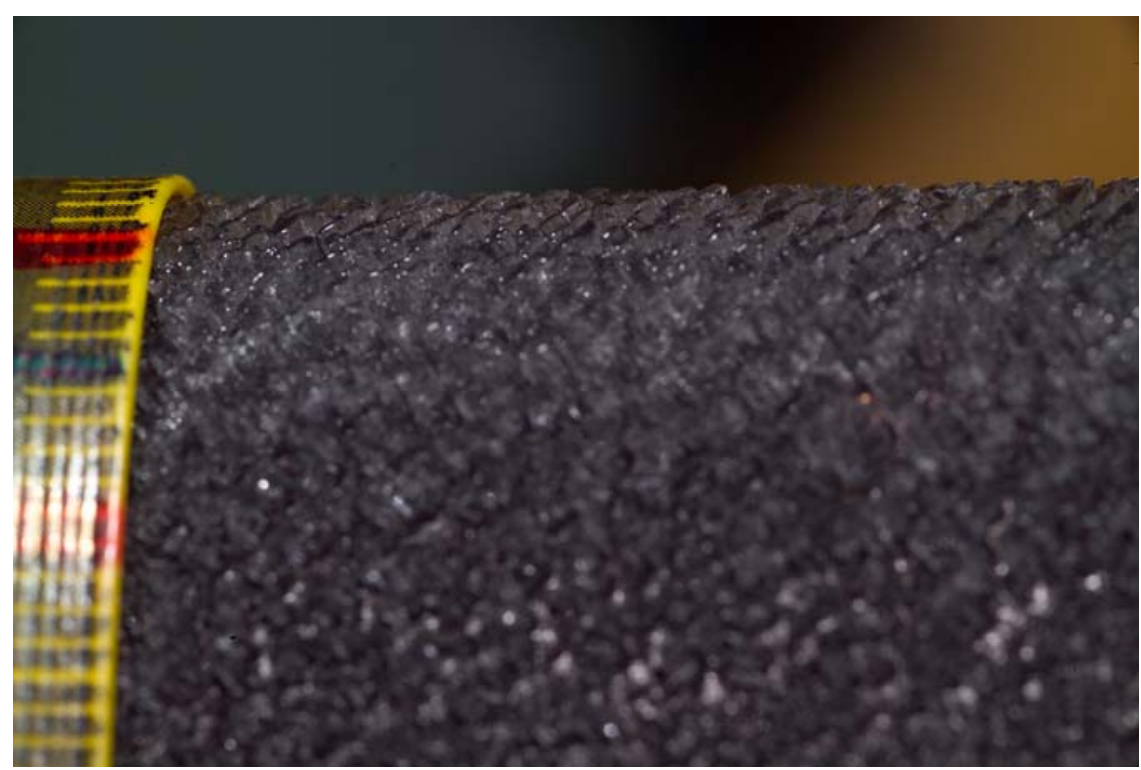

Figure 12.-Ridges are main feature after $60 \mathrm{sec} . \Lambda=45^{\circ}, \mathrm{V}=150 \mathrm{mph}, \mathrm{T}_{\text {total }}=$ $25^{\circ} \mathrm{F}, \mathrm{LWC}=0.75 \mathrm{~g} / \mathrm{m}^{3}, \mathrm{MVD}=20 \mu \mathrm{m}, \tau=60 \mathrm{sec}$. Direction of flow is from left to right. Smallest scale on tape is $1 \mathrm{~mm}$.

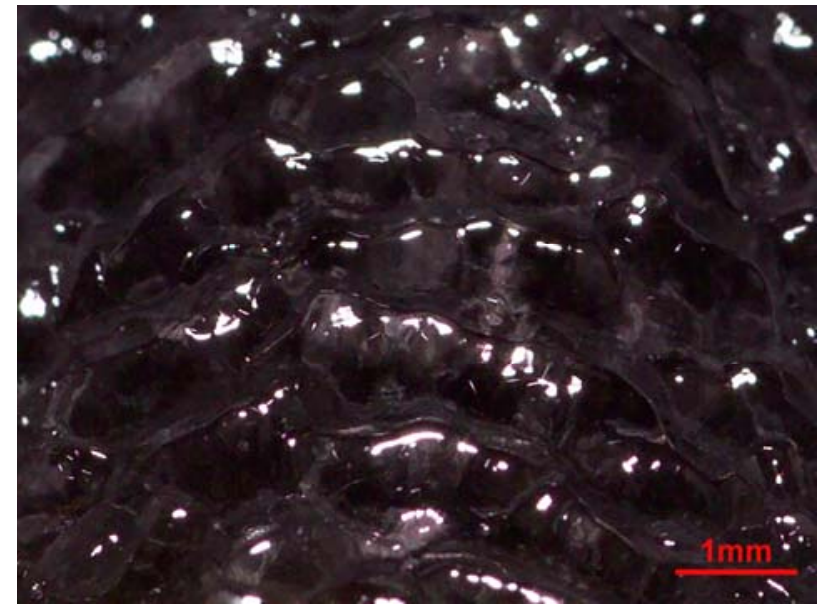

Figure 13.-Close-up of ridges after $60 \mathrm{sec} . \Lambda=45^{\circ}$, $\mathrm{V}=150 \mathrm{mph}, \mathrm{T}_{\text {total }}=25^{\circ} \mathrm{F}, \mathrm{LWC}=0.75 \mathrm{~g} / \mathrm{m}^{3}, \mathrm{MVD}=$ $20 \mu \mathrm{m}, \tau=60 \mathrm{sec}$. Direction of flow is from bottom to top.

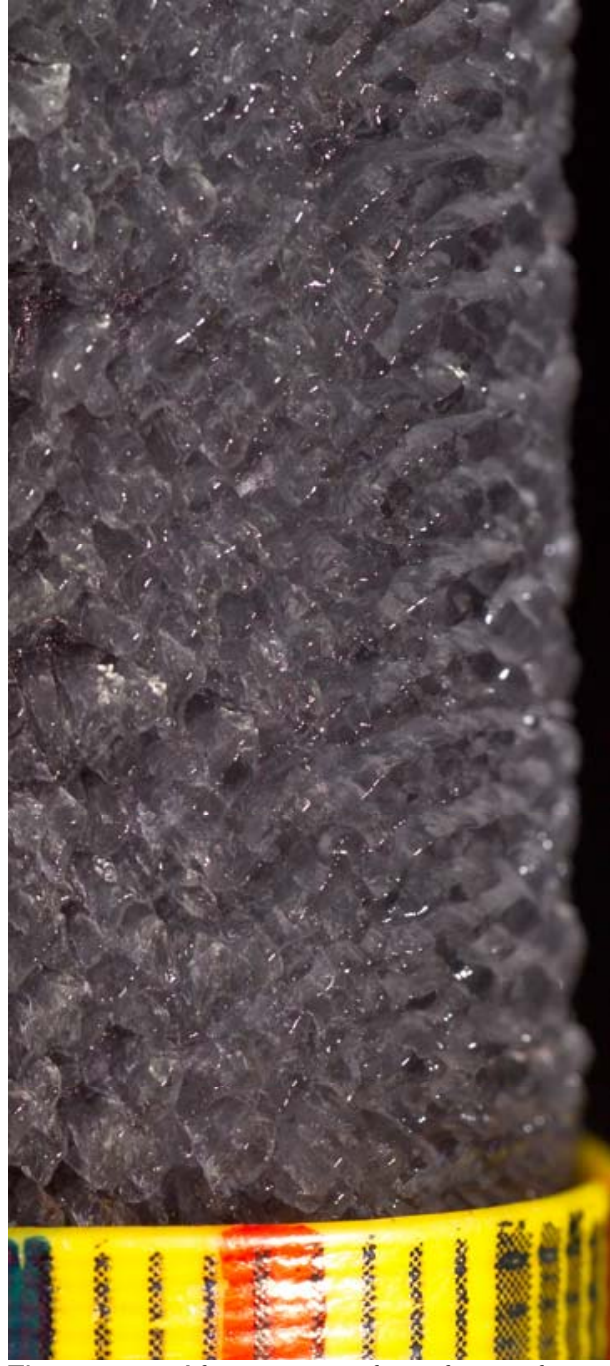

Figure 14.-After $70 \mathrm{sec}$., front facet of ridges grows away from surface. $\Lambda=45^{\circ}$, $\mathrm{V}=150 \mathrm{mph}, \mathrm{T}_{\text {total }}=25^{\circ} \mathrm{F}, \mathrm{LWC}=$ $0.75 \mathrm{~g} / \mathrm{m}^{3}, \mathrm{MVD}=20 \mu \mathrm{m}, \tau=70 \mathrm{sec}$. Direction of flow is from bottom to top. Smallest scale on tape is $1 \mathrm{~mm}$. 


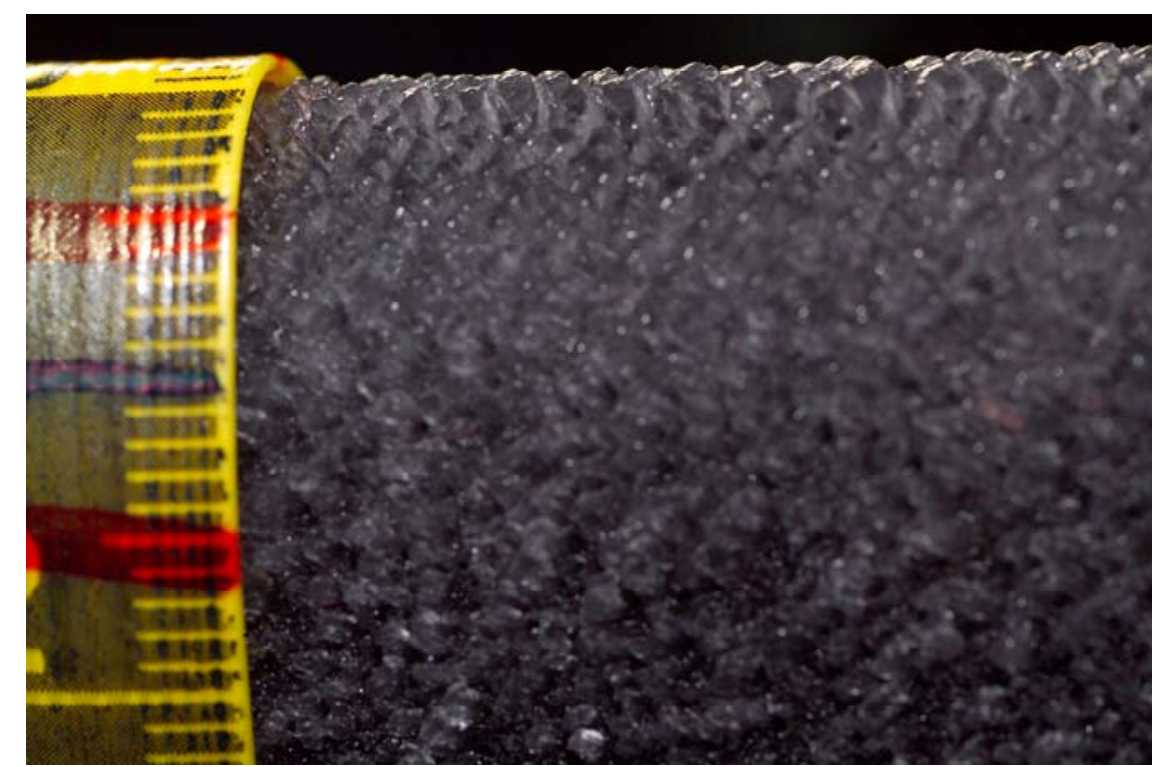

Figure 15.-After $70 \mathrm{sec}$, front facet of ridges grows away from surface. $\Lambda=45^{\circ}$, $V=150 \mathrm{mph}, \mathrm{T}_{\text {total }}=25^{\circ} \mathrm{F}, \mathrm{LWC}=0.75 \mathrm{~g} / \mathrm{m}^{3}, \mathrm{MVD}=20 \mu \mathrm{m}, \tau=70 \mathrm{sec}$.

Direction of flow is from left to right. Smallest scale on tape is $1 \mathrm{~mm}$.

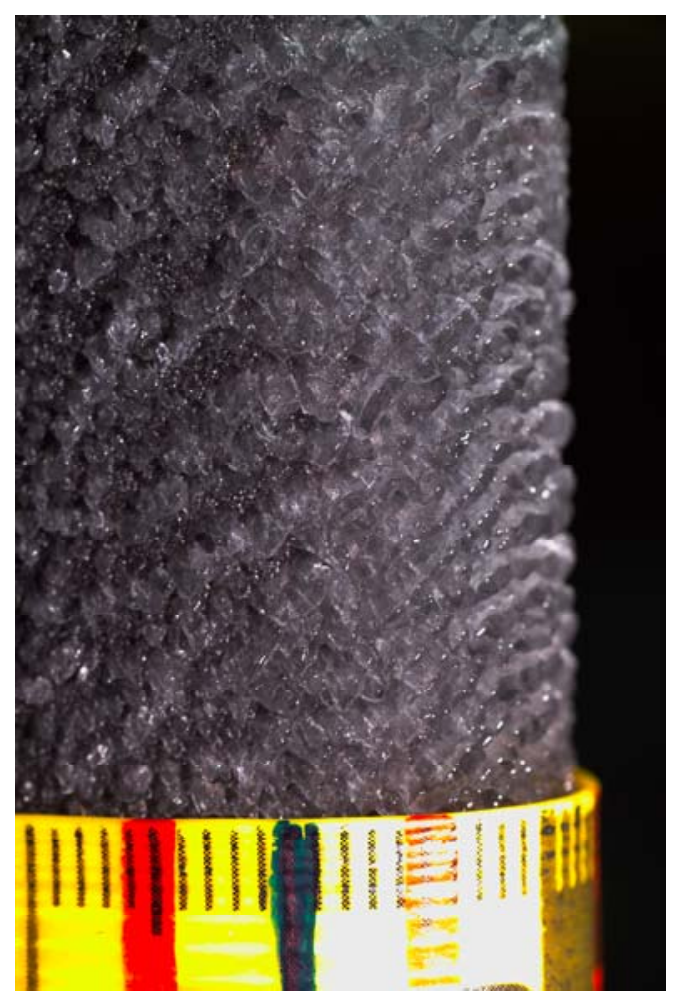

Figure 16.-After $80 \mathrm{sec}$, front facet of ridges continues to grow away from surface and feathers become more apparent. $\Lambda=45^{\circ}$, $\mathrm{V}=150 \mathrm{mph}, \mathrm{T}_{\text {total }}=25^{\circ} \mathrm{F}, \mathrm{LWC}=$ $0.75 \mathrm{~g} / \mathrm{m}^{3}, \mathrm{MVD}=20 \mu \mathrm{m}, \tau=80 \mathrm{sec}$. Direction of flow is from bottom to top. Smallest scale on tape is $1 \mathrm{~mm}$.

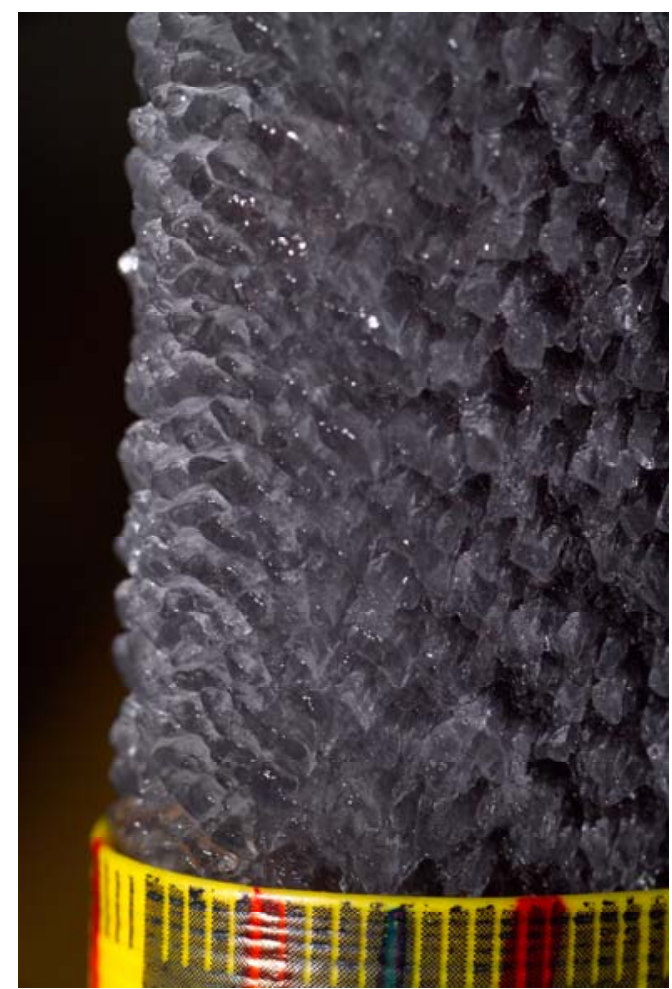

Figure 17.-After $120 \mathrm{sec}$, front facet of ridges continues to grow away from surface and feathers become larger. $\Lambda=45^{\circ}, V=$ $150 \mathrm{mph}, \mathrm{T}_{\text {total }}=25^{\circ} \mathrm{F}, \mathrm{LWC}=0.75 \mathrm{~g} / \mathrm{m}^{3}$, MVD $=20 \mu \mathrm{m}, \tau=120 \mathrm{sec}$. Direction of flow is from bottom to top. Smallest scale on tape is $1 \mathrm{~mm}$. 


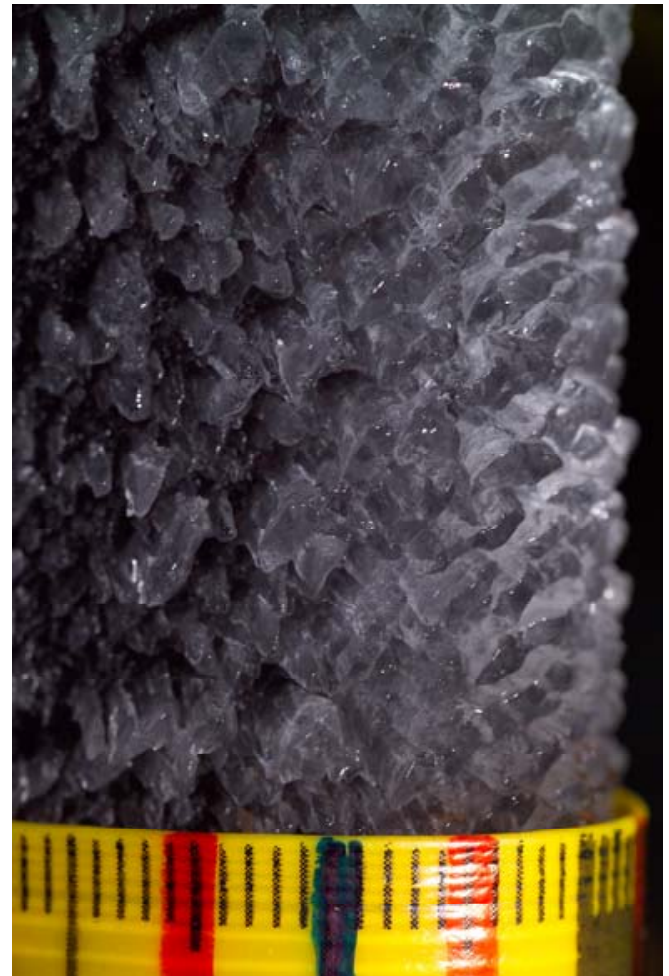

Figure 18.-After $150 \mathrm{sec}$, feathers become larger. $\Lambda=45^{\circ}, V=150 \mathrm{mph}, \mathrm{T}_{\text {total }}=25^{\circ} \mathrm{F}$, $\mathrm{LWC}=0.75 \mathrm{~g} / \mathrm{m}^{3}, \mathrm{MVD}=20 \mu \mathrm{m}$, $\tau=150 \mathrm{sec}$. Direction of flow is from bottom to top. Smallest scale on tape is $1 \mathrm{~mm}$.

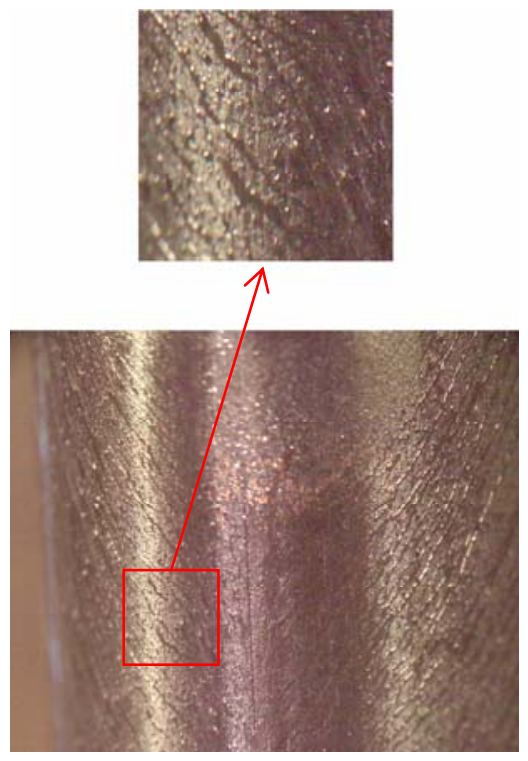

Figure 20.-Time-sequence photograph after $3 \mathrm{sec}$, showing water flow and droplets. $\Lambda=45^{\circ}, \mathrm{V}=150 \mathrm{mph}$, $\mathrm{T}_{\text {total }}=25^{\circ} \mathrm{F}, \mathrm{LWC}=0.75 \mathrm{~g} / \mathrm{m}^{3}$, $M V D=20 \mu \mathrm{m}$. Direction of flow is from bottom to top.

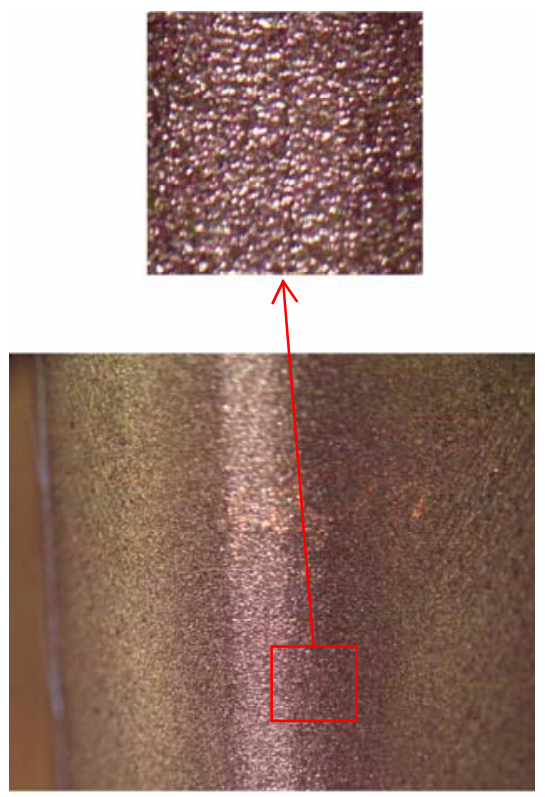

Figure 21.-Time-sequence photograph after $6 \mathrm{sec}$, showing roughness elements. $\Lambda=45^{\circ}$, $\mathrm{V}=150 \mathrm{mph}, \mathrm{T}_{\text {total }}=25^{\circ} \mathrm{F}, \mathrm{LWC}=$ $0.75 \mathrm{~g} / \mathrm{m}^{3}, \mathrm{MVD}=20 \mu \mathrm{m}$. Direction of flow is from bottom to top.

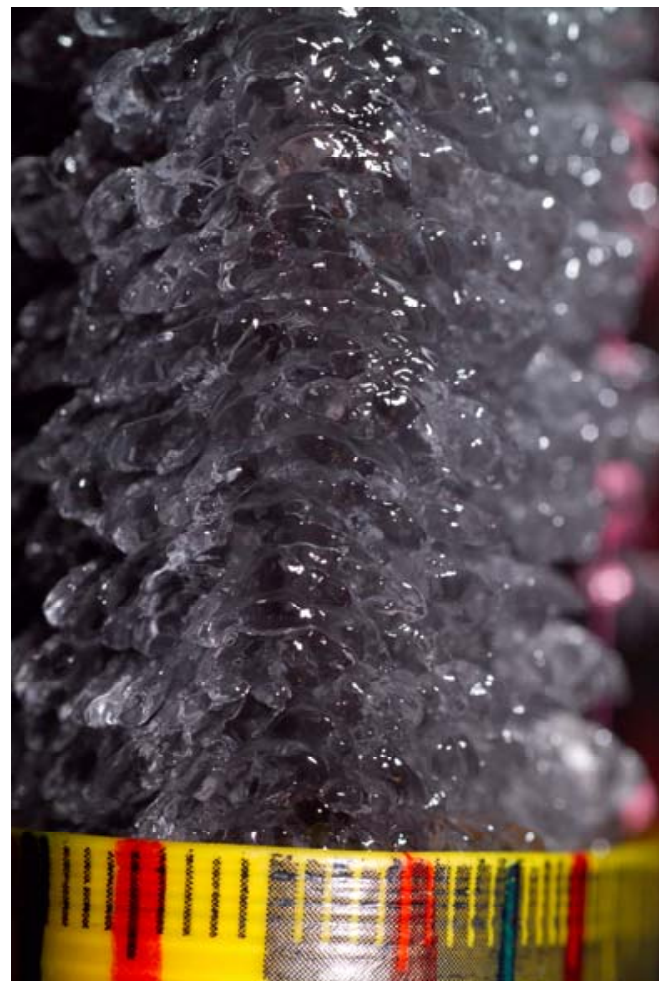

Figure 19._-Large feathers forming initial scallop tips after $180 \mathrm{sec} . \Lambda=45^{\circ}$, $\mathrm{V}=150 \mathrm{mph}, \mathrm{T}_{\text {total }}=25^{\circ} \mathrm{F}, \mathrm{LWC}=$ $0.75 \mathrm{~g} / \mathrm{m}^{3}, \mathrm{MVD}=20 \mu \mathrm{m}, \tau=180 \mathrm{sec}$. Direction of flow is from bottom to top. Smallest scale on tape is $1 \mathrm{~mm}$.

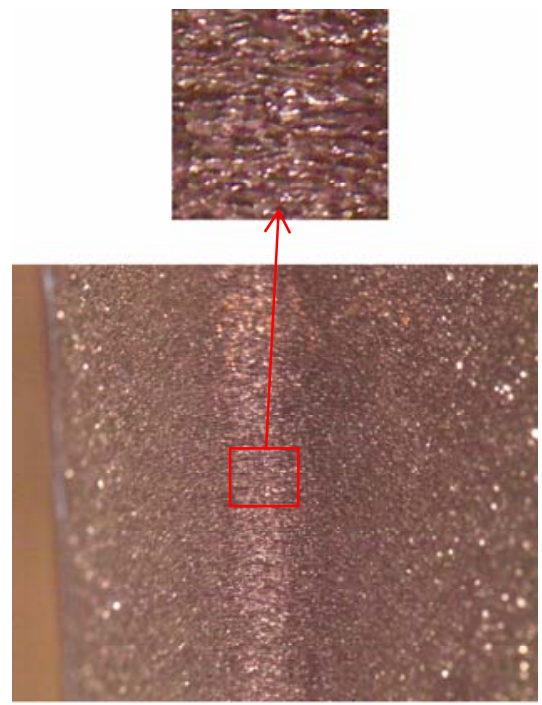

Figure 22.-Time-sequence photograph after $21 \mathrm{sec}$, showing ridges. $\Lambda=45^{\circ}, V=150 \mathrm{mph}, \mathrm{T}_{\text {total }}$ $=25^{\circ} \mathrm{F}, \mathrm{LWC}=0.75 \mathrm{~g} / \mathrm{m}^{3}, \mathrm{MVD}=$ $20 \mu \mathrm{m}$. Direction of flow is from bottom to top. 


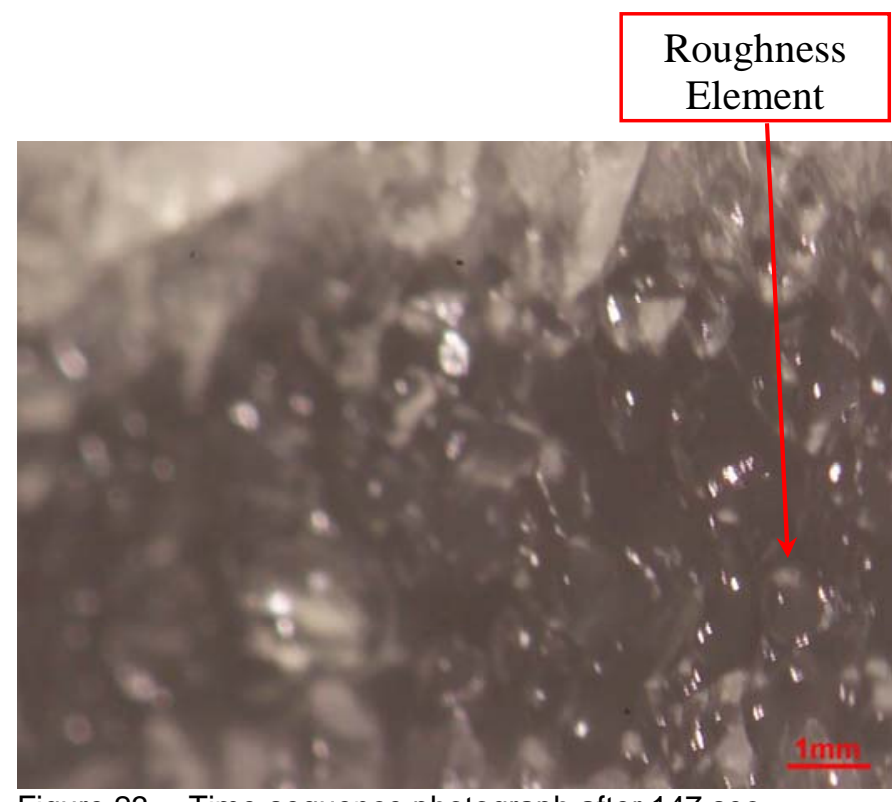

Figure 23.-Time-sequence photograph after $147 \mathrm{sec}$,

hemispherical roughness element on the surface. $\Lambda=30^{\circ}$, $\mathrm{V}=225 \mathrm{mph}, \mathrm{T}_{\text {total }}=25^{\circ} \mathrm{F}, \mathrm{LWC}=0.553 \mathrm{~g} / \mathrm{m}^{3}$, MVD $=15.1 \mu \mathrm{m}$. Direction of flow is from bottom to top.

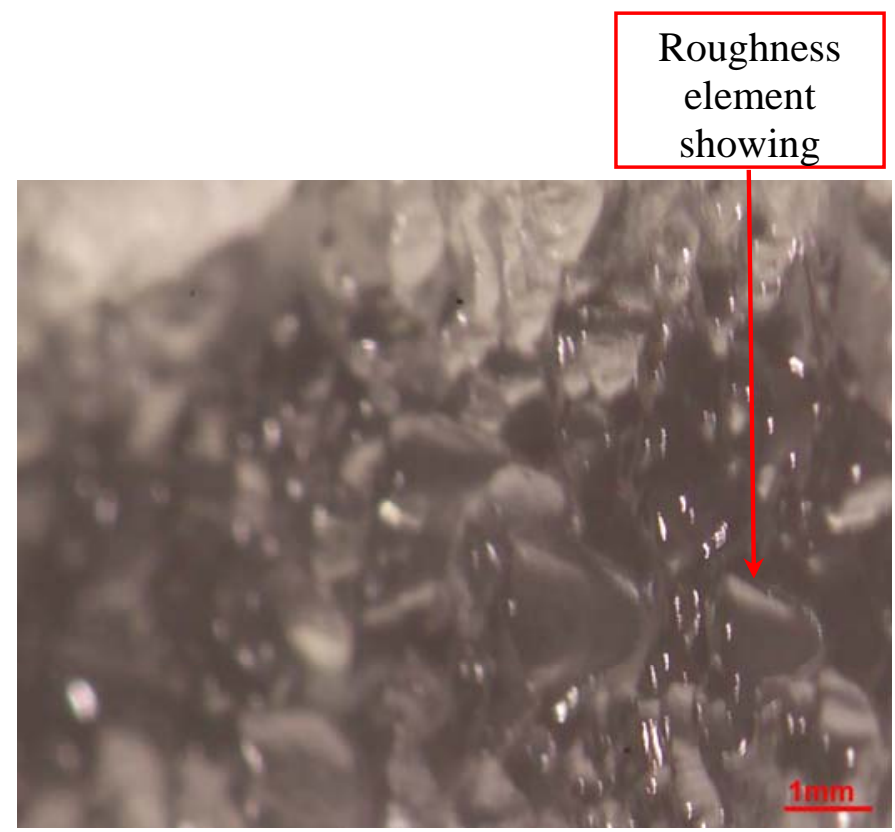

Figure 25.-Time-sequence photograph after $162 \mathrm{sec}$,

roughness element has developed a pointed shape. $\Lambda=30^{\circ}$, $\mathrm{V}=225 \mathrm{mph}, \mathrm{T}_{\text {total }}=25^{\circ} \mathrm{F}, \mathrm{LWC}=0.553 \mathrm{~g} / \mathrm{m}^{3}, \mathrm{MVD}=$ $15.1 \mu \mathrm{m}$. Direction of flow is from bottom to top.

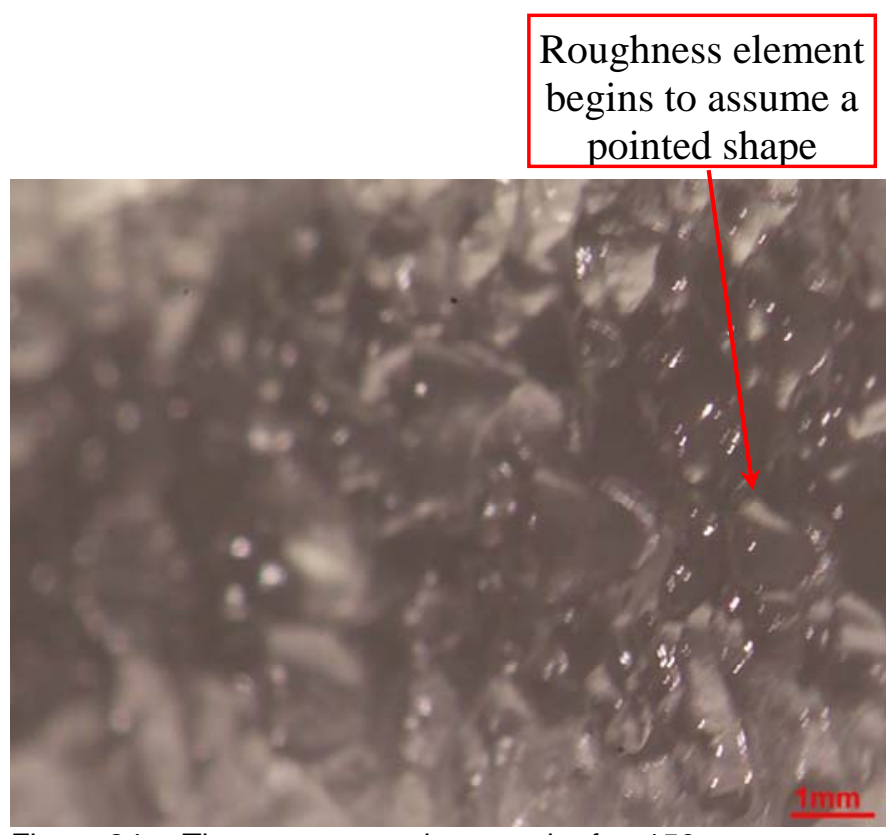

Figure 24.-Time-sequence photograph after $156 \mathrm{sec}$, roughness element begins to assume a pointed shape. $\Lambda=30^{\circ}, V=225 \mathrm{mph}, \mathrm{T}_{\text {total }}=25^{\circ} \mathrm{F}, \mathrm{LWC}=0.553 \mathrm{~g} / \mathrm{m}^{3}$, $M V D=15.1 \mu \mathrm{m}$. Direction of flow is from bottom to top.

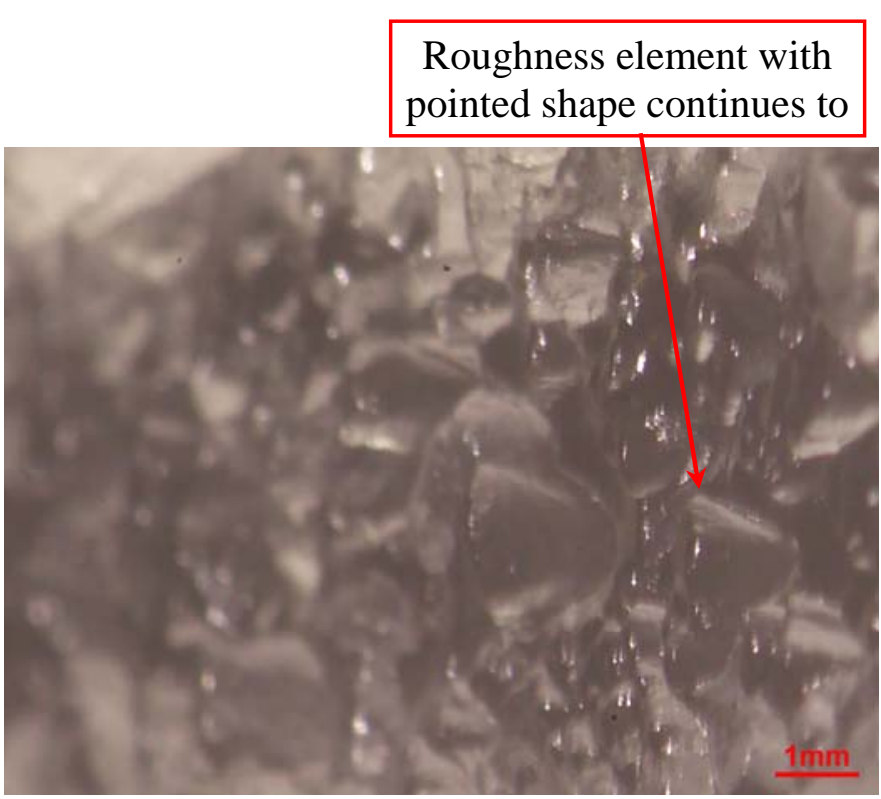

Figure 26.-Time-sequence photograph after $168 \mathrm{sec}$, roughness element with pointed shape continues to grow. $\Lambda=30^{\circ}, \mathrm{V}=225 \mathrm{mph}, \mathrm{T}_{\text {total }}=25^{\circ} \mathrm{F}, \mathrm{LWC}=0.553 \mathrm{~g} / \mathrm{m}^{3}$, $M V D=15.1 \mu \mathrm{m}$. Direction of flow is from bottom to top. 


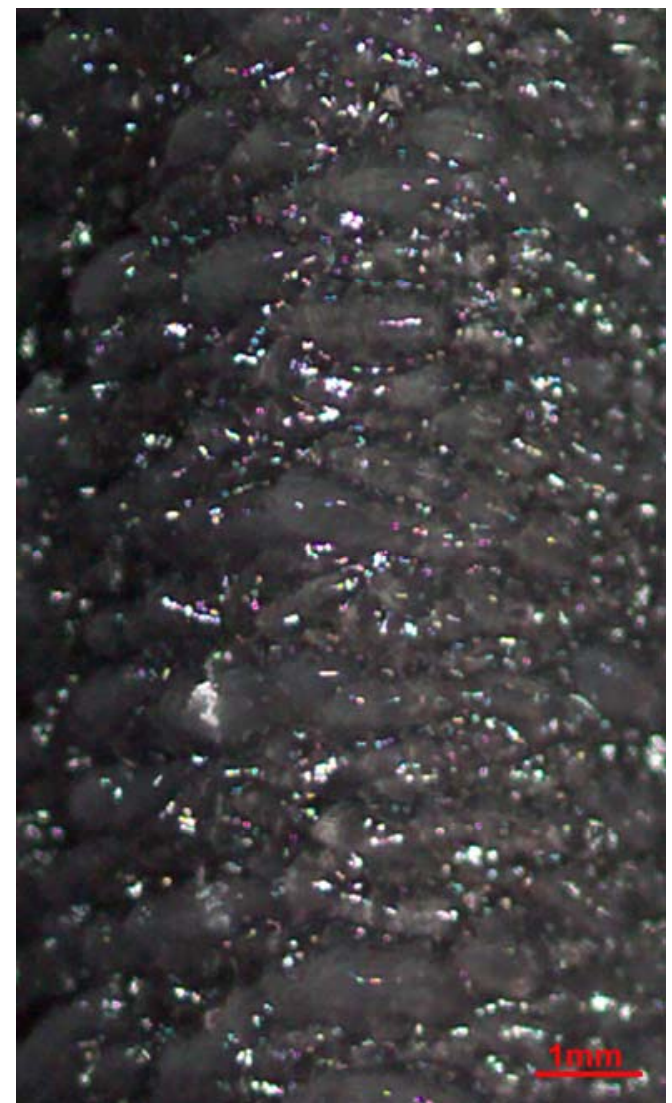

Figure 27.-Ridges forming after $10 \mathrm{sec}$. SLD condition of $\Lambda=45^{\circ}, \mathrm{V}=172.7 \mathrm{mph}, \mathrm{T}_{\text {total }}=$ $10^{\circ} \mathrm{F}, \mathrm{LWC}=0.75 \mathrm{~g} / \mathrm{m}^{3}, \mathrm{MVD}=200 \mu \mathrm{m}$, $\tau=10 \mathrm{sec}$. Direction of flow is from bottom to top.

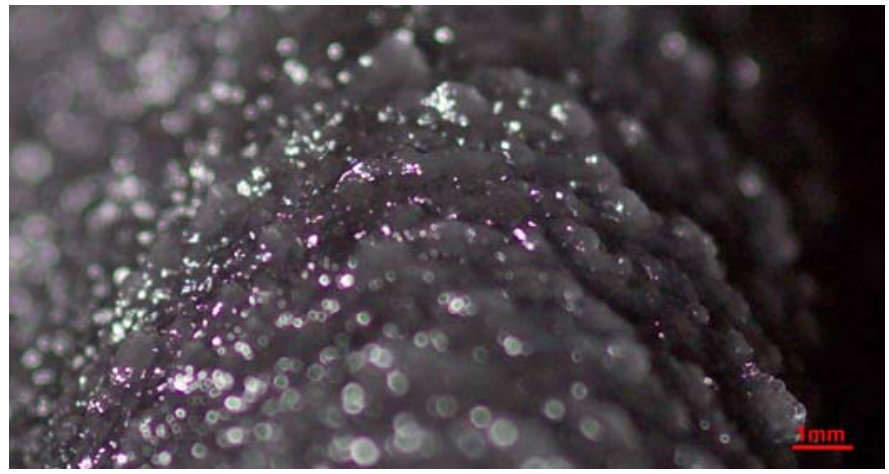

Figure 29.--Ridges forming after $10 \mathrm{sec}$, viewed from a grazing angle. SLD condition of $\Lambda=45^{\circ}, V=172.7 \mathrm{mph}$, $\mathrm{T}_{\text {total }}=10^{\circ} \mathrm{F}, \mathrm{LWC}=0.75 \mathrm{~g} / \mathrm{m}^{3}, \mathrm{MVD}=200 \mu \mathrm{m}, \tau=10 \mathrm{sec}$. Direction of flow is from bottom to top.

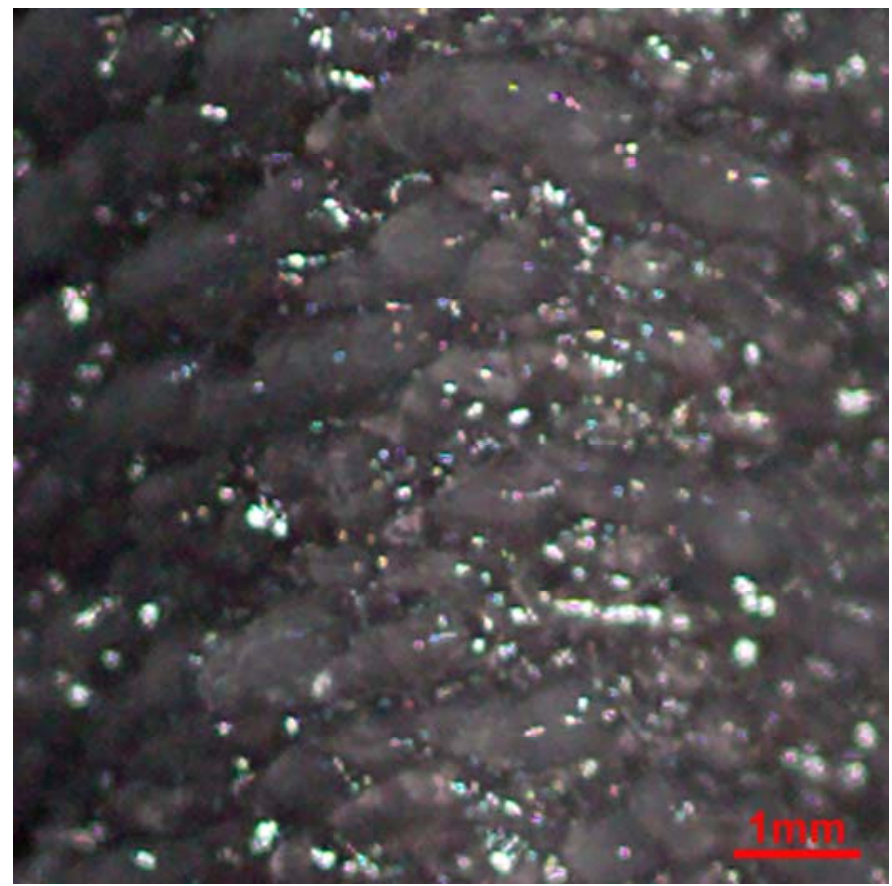

Figure 28.-Close-up of ridges after $10 \mathrm{sec}$. SLD condition of $\Lambda=45^{\circ}, \mathrm{V}=172.7 \mathrm{mph}, \mathrm{T}_{\text {total }}=10^{\circ} \mathrm{F}, \mathrm{LWC}=0.75 \mathrm{~g} / \mathrm{m}^{3}, \mathrm{MVD}$ $=200 \mu \mathrm{m}, \tau=10 \mathrm{sec}$. Direction of flow is from bottom to top.

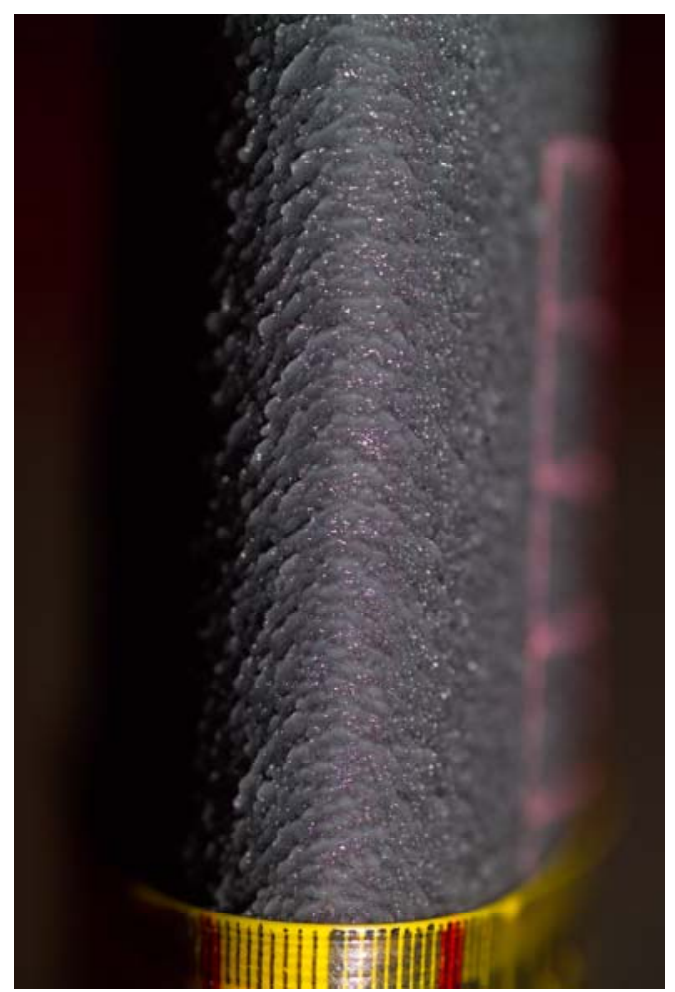

Figure 30.- Overall view of ridges after $15 \mathrm{sec}$. SLD condition of $\Lambda=45^{\circ}, \mathrm{V}=$ $172.7 \mathrm{mph}, \mathrm{T}_{\text {total }}=10^{\circ} \mathrm{F}, \mathrm{LWC}=0.75 \mathrm{~g} / \mathrm{m}^{3}$, MVD $=200 \mu \mathrm{m}, \tau=15 \mathrm{sec}$. Direction of flow is from bottom to top. Smallest scale on tape is $1 \mathrm{~mm}$. 


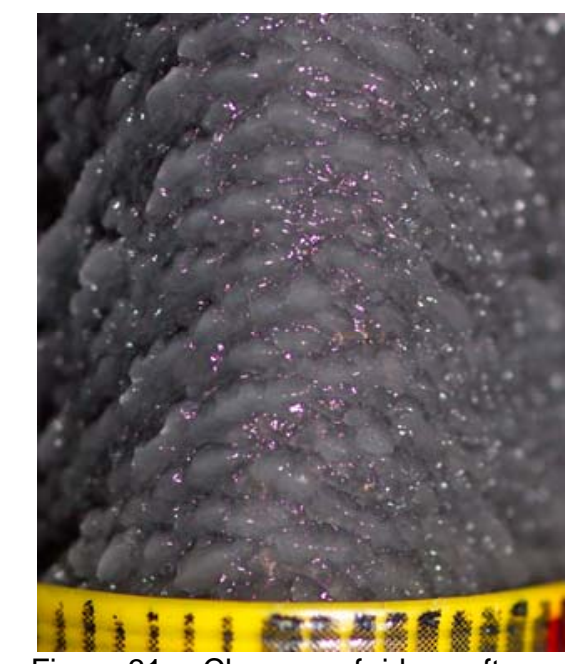

Figure 31.-Close-up of ridges after 15 sec. SLD condition of $\Lambda=45^{\circ}$, $\mathrm{V}=172.7 \mathrm{mph}, \mathrm{T}_{\text {total }}=10^{\circ} \mathrm{F}, \mathrm{LWC}$ $=0.75 \mathrm{~g} / \mathrm{m}^{3}, \mathrm{MVD}=200 \mu \mathrm{m}, \tau=$ $15 \mathrm{sec}$. Direction of flow is from bottom to top. Smallest scale on tape is $1 \mathrm{~mm}$.

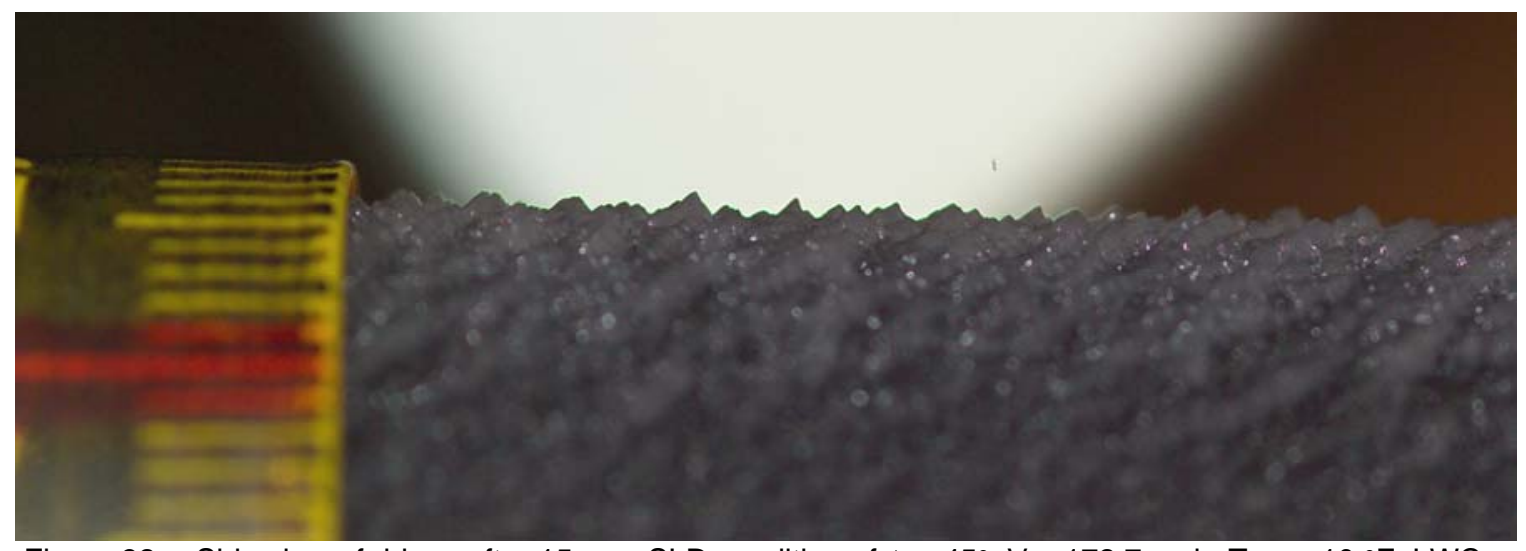

Figure 32.-Side view of ridges after $15 \mathrm{sec}$. SLD condition of $\Lambda=45^{\circ}, \mathrm{V}=172.7 \mathrm{mph}, \mathrm{T}_{\text {total }}=10^{\circ} \mathrm{F}, \mathrm{LWC}=$ $0.75 \mathrm{~g} / \mathrm{m}^{3}, \mathrm{MVD}=200 \mu \mathrm{m}, \tau=15 \mathrm{sec}$. Direction of flow is from left to right. Smallest scale on tape is $1 \mathrm{~mm}$.

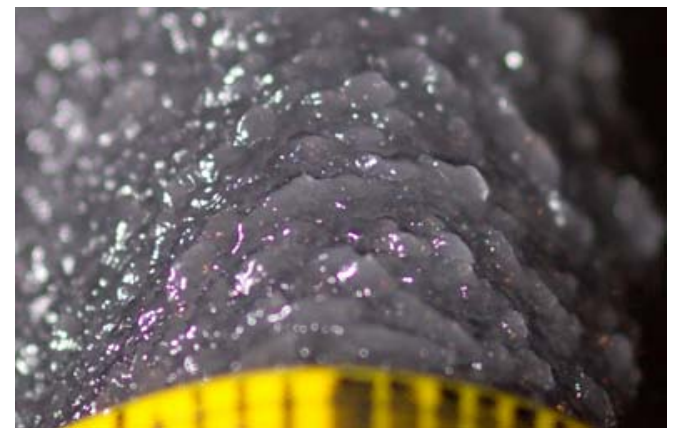

Figure 33.--Ridges after $15 \mathrm{sec}$, viewed at a grazing angle. SLD condition of $\Lambda=45^{\circ}$, $\mathrm{V}=172.7 \mathrm{mph}, \mathrm{T}_{\text {total }}=10^{\circ} \mathrm{F}, \mathrm{LWC}=$ $0.75 \mathrm{~g} / \mathrm{m}^{3}, \mathrm{MVD}=200 \mu \mathrm{m}, \tau=15 \mathrm{sec}$. Direction of flow is from bottom to top. Smallest scale on tape is $1 \mathrm{~mm}$.

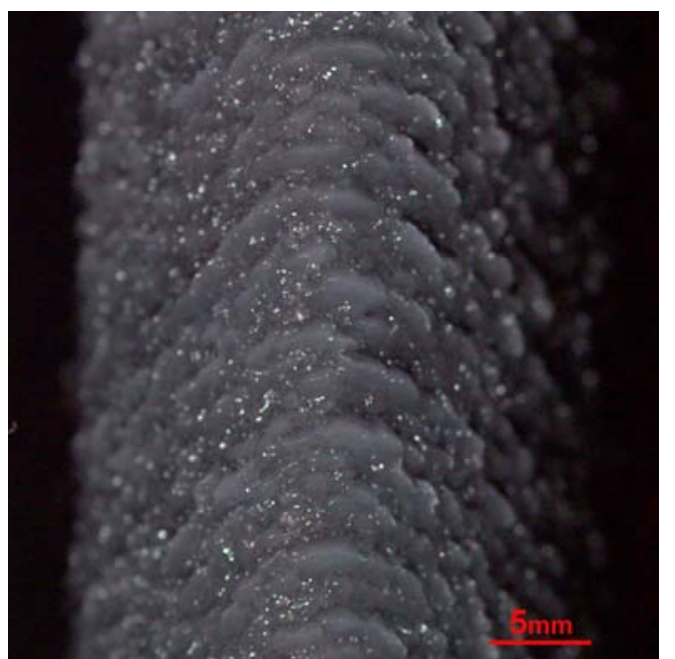

Figure 34.-Ridges after $20 \mathrm{sec}$, showing front facet. SLD condition of $\Lambda=45^{\circ}, V=172.7 \mathrm{mph}$, $\mathrm{T}_{\text {total }}=10^{\circ} \mathrm{F}, \mathrm{LWC}=0.75 \mathrm{~g} / \mathrm{m}^{3}, \mathrm{MVD}=200 \mu \mathrm{m}$, $M V D=200 \mathrm{sec}$. Direction of flow is from bottom to top. 


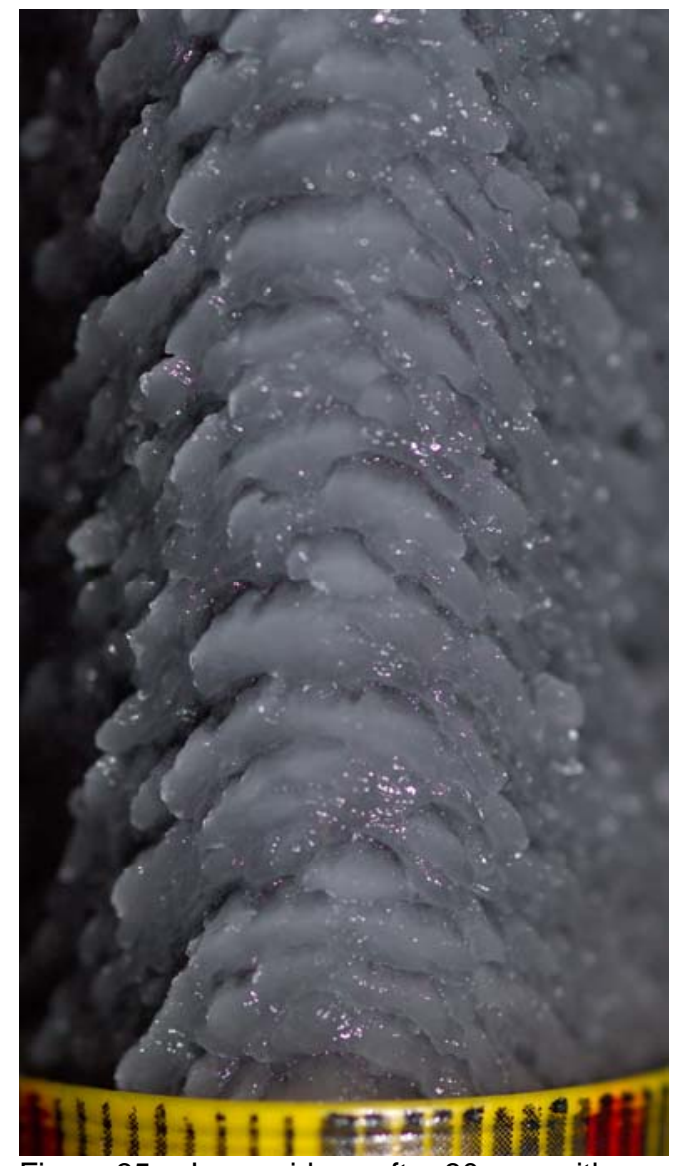

Figure 35.—Large ridges after $30 \mathrm{sec}$, with front facet starting to grow away from surface. SLD condition of $\Lambda=45^{\circ}, V=$ $172.7 \mathrm{mph}, \mathrm{T}_{\text {total }}=10^{\circ} \mathrm{F}, \mathrm{LWC}=0.75 \mathrm{~g} / \mathrm{m}^{3}$, MVD $=200 \mu \mathrm{m}, \tau=30 \mathrm{sec}$. Direction of flow is from bottom to top. Smallest scale on tape is $1 \mathrm{~mm}$.

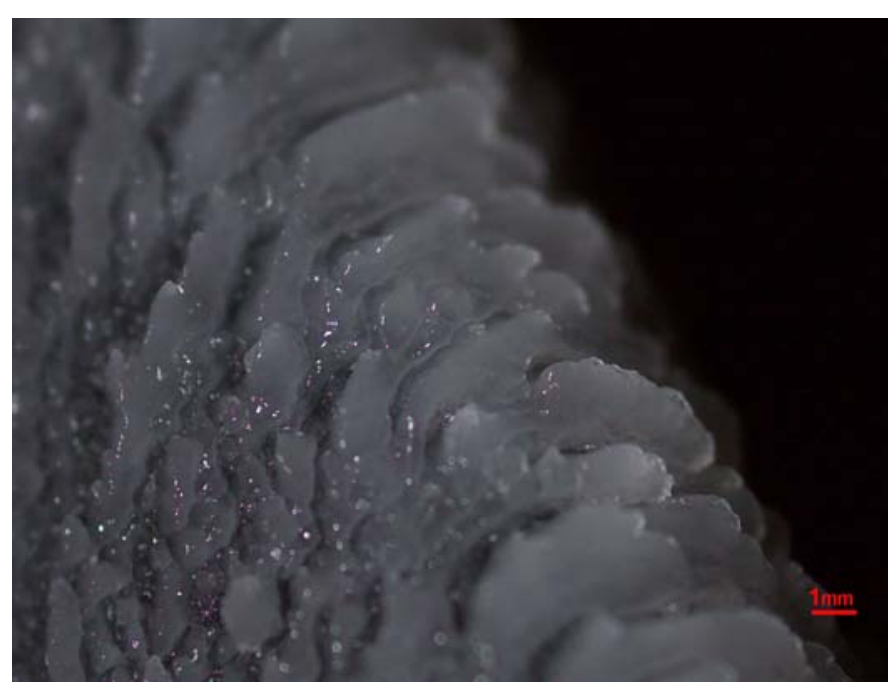

Figure 36.- Large ridges after $30 \mathrm{sec}$, with front facet starting to grow away from surface. SLD condition of $\Lambda=45^{\circ}, V=$ $172.7 \mathrm{mph}, \mathrm{T}_{\text {total }}=10^{\circ} \mathrm{F}, \mathrm{LWC}=0.75 \mathrm{~g} / \mathrm{m}^{3}, \mathrm{MVD}=200 \mu \mathrm{m}$, $\tau=30 \mathrm{sec}$. Direction of flow is from bottom to top.

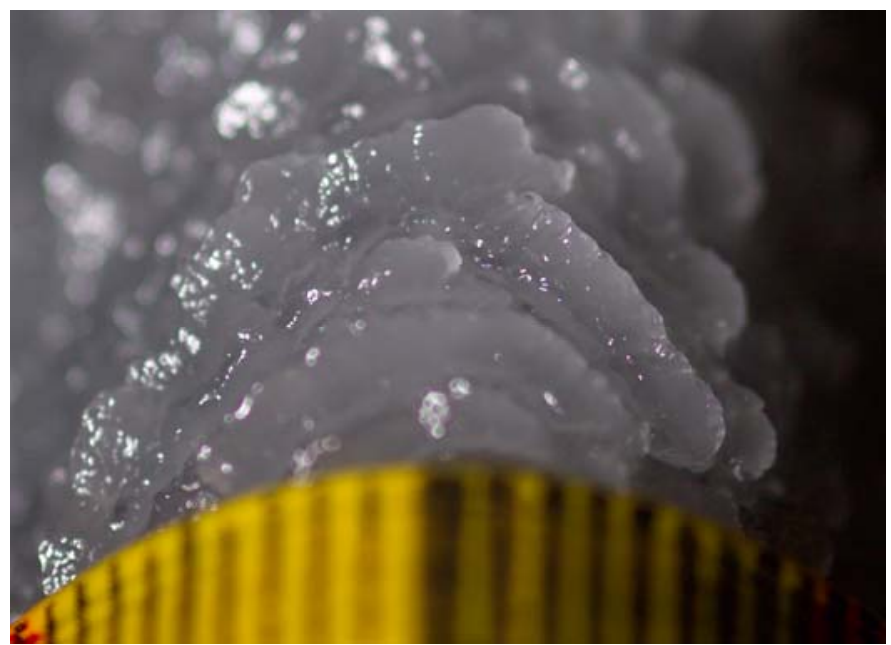

Figure 37.-Close-up of large ridges and their front facets after $40 \mathrm{sec}$. SLD condition of $\Lambda=45^{\circ}, \mathrm{V}=172.7 \mathrm{mph}, \mathrm{T}_{\text {total }}=$ $10^{\circ} \mathrm{F}, \mathrm{LWC}=0.75 \mathrm{~g} / \mathrm{m}^{3}, \mathrm{MVD}=200 \mu \mathrm{m}, \tau=40 \mathrm{sec}$.

Direction of flow is from bottom to top. Smallest scale on tape is $1 \mathrm{~mm}$.

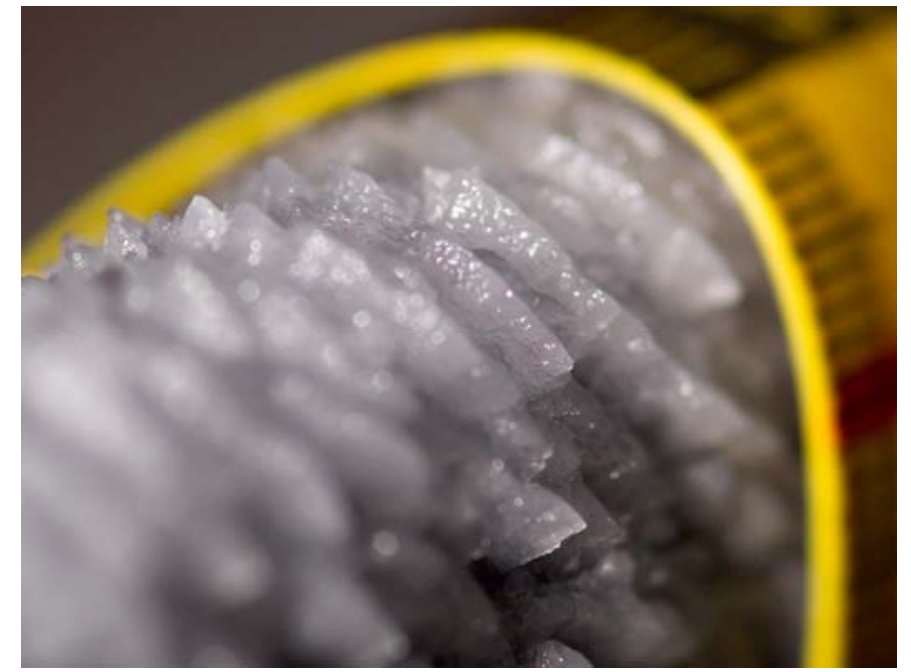

Figure 38.- - Large ridges after $40 \mathrm{sec}$, viewed at a grazing angle. SLD condition of $\Lambda=45^{\circ}, \mathrm{V}=172.7 \mathrm{mph}, \mathrm{T}_{\text {total }}=$ $10^{\circ} \mathrm{F}, \mathrm{LWC}=0.75 \mathrm{~g} / \mathrm{m}^{3}, \mathrm{MVD}=200 \mu \mathrm{m}, \tau=40 \mathrm{sec}$. Direction of flow is from upper right corner to lower left corner. Smallest scale on tape is $1 \mathrm{~mm}$. 


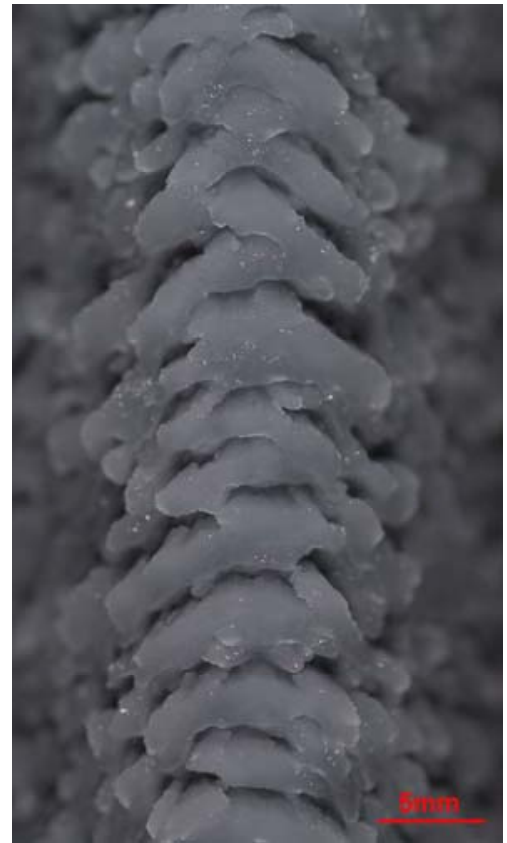

Figure 39.-Front facets of ridges begin to form feathers after

$50 \mathrm{sec}$. SLD condition of $\Lambda=45^{\circ}$, $\mathrm{V}=172.7 \mathrm{mph}, \mathrm{T}_{\text {total }}=10^{\circ} \mathrm{F}$, $\mathrm{LWC}=0.75 \mathrm{~g} / \mathrm{m}^{3}, \mathrm{MVD}=$ $200 \mu \mathrm{m}, \tau=50 \mathrm{sec}$. Direction of flow is from bottom to top.

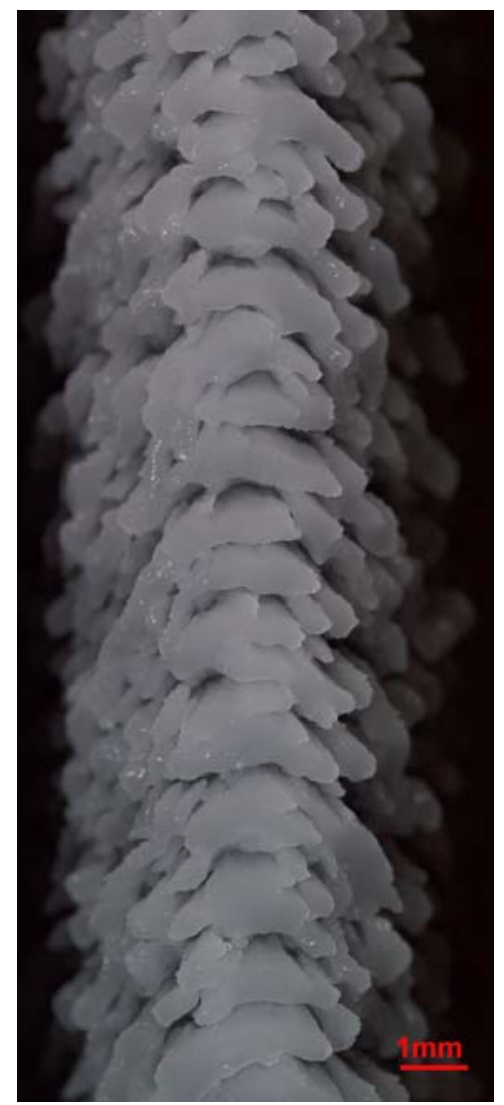

Figure 41.-Well-defined scallop tips after $90 \mathrm{sec}$. SLD condition of $\Lambda=45^{\circ}, V=172.7 \mathrm{mph}, \mathrm{T}_{\text {total }}$ $=10^{\circ} \mathrm{F}, \mathrm{LWC}=0.75 \mathrm{~g} / \mathrm{m}^{3}, \mathrm{MVD}$ $=200 \mu \mathrm{m}, \tau=90 \mathrm{sec}$. Direction of flow is from bottom to top.

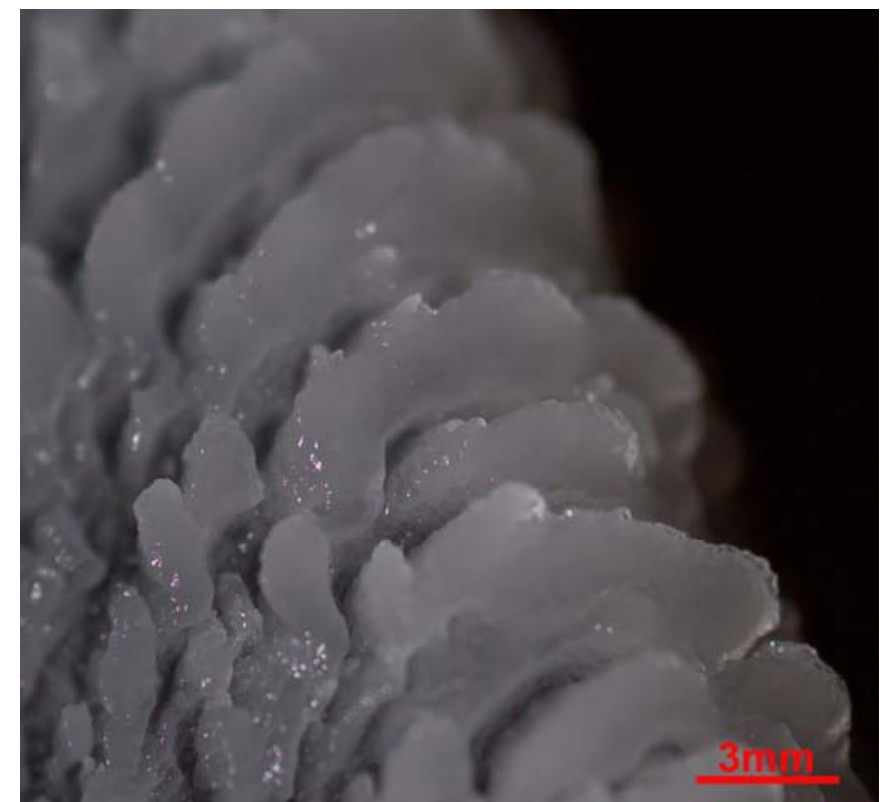

Figure 40.-Front facets of ridges begin to form feathers after $50 \mathrm{sec}$. SLD condition of $\Lambda=45^{\circ}, \mathrm{V}=172.7 \mathrm{mph}, \mathrm{T}_{\text {total }}=$ $10^{\circ} \mathrm{F}, \mathrm{LWC}=0.75 \mathrm{~g} / \mathrm{m}^{3}, \mathrm{MVD}=200 \mu \mathrm{m}, \tau=50 \mathrm{sec}$. Direction of flow is from bottom to top.

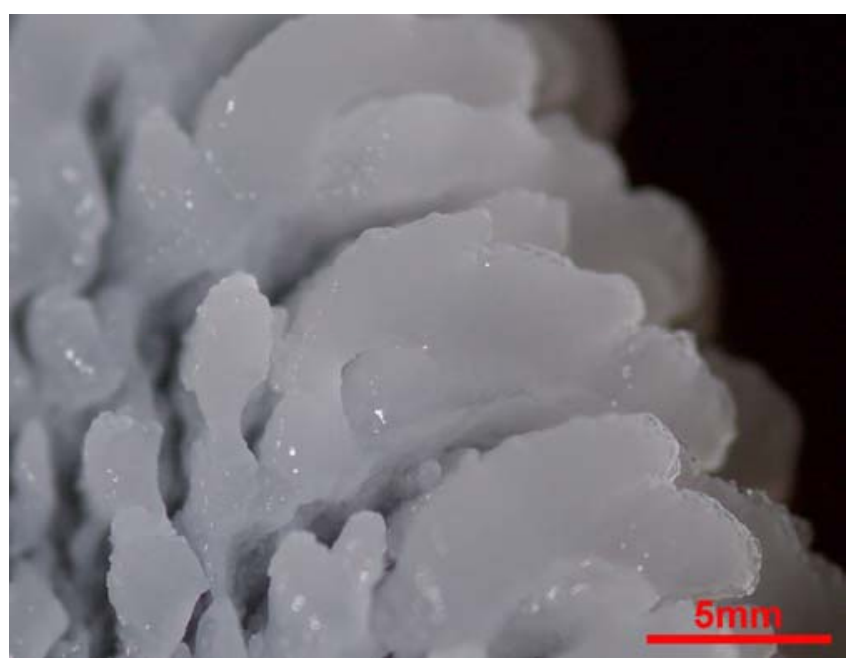

Figure 42.-Close-up of well-defined scallop tips after 90 sec. SLD condition of $\Lambda=45^{\circ}, \mathrm{V}=172.7 \mathrm{mph}, \mathrm{T}_{\text {total }}=10^{\circ} \mathrm{F}$, LWC $=0.75 \mathrm{~g} / \mathrm{m}^{3}, \mathrm{MVD}=200 \mu \mathrm{m}, \tau=90 \mathrm{sec}$. Direction of flow is from bottom to top. 


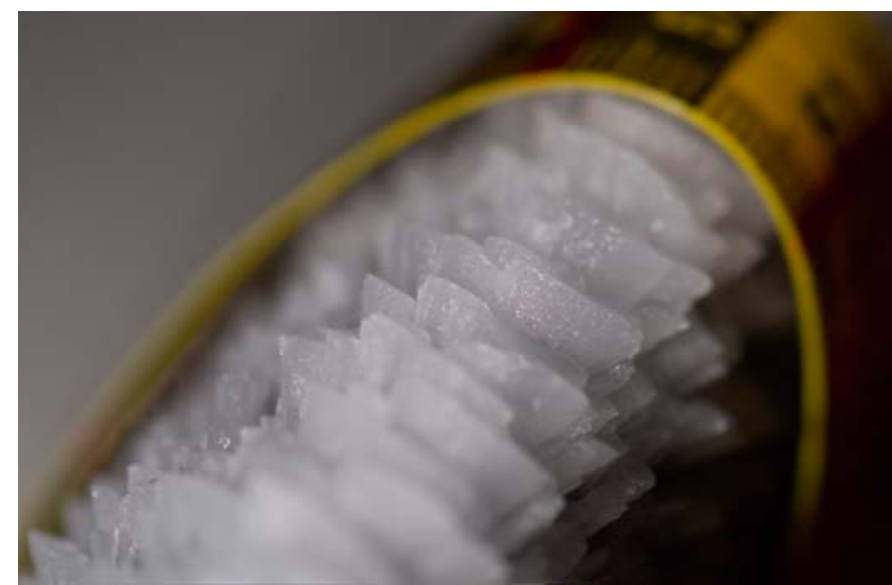

Figure 43.-Well-defined scallop tips after $90 \mathrm{sec}$, viewed at a grazing angle. SLD condition of $\Lambda=45^{\circ}, \mathrm{V}=172.7 \mathrm{mph}$, $\mathrm{T}_{\text {total }}=10^{\circ} \mathrm{F}, \mathrm{LWC}=0.75 \mathrm{~g} / \mathrm{m}^{3}, \mathrm{MVD}=200 \mu \mathrm{m}, \tau=90 \mathrm{sec}$. Direction of flow is from upper right corner to lower left corner. Smallest scale on tape is $1 \mathrm{~mm}$.

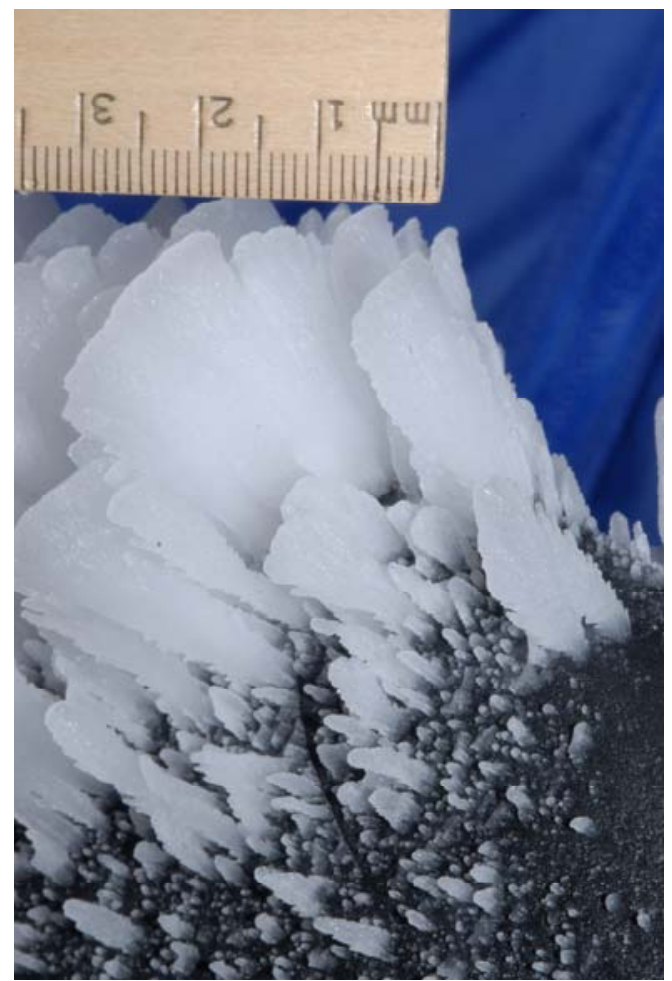

Figure 45.-Glaze ice formation with feathers as part of main ice accretion, as well as individual feathers. SLD condition of $\Lambda=$ $45^{\circ}, \mathrm{V}=172.7 \mathrm{mph}, \mathrm{T}_{\text {total }}=10^{\circ} \mathrm{F}, \mathrm{LWC}=$ $0.75 \mathrm{~g} / \mathrm{m}^{3}, \mathrm{MVD}=200 \mu \mathrm{m}, \tau=10 \mathrm{~min}$. Direction of flow is from bottom to top. Smallest scale on ruler is $1 \mathrm{~mm}$.

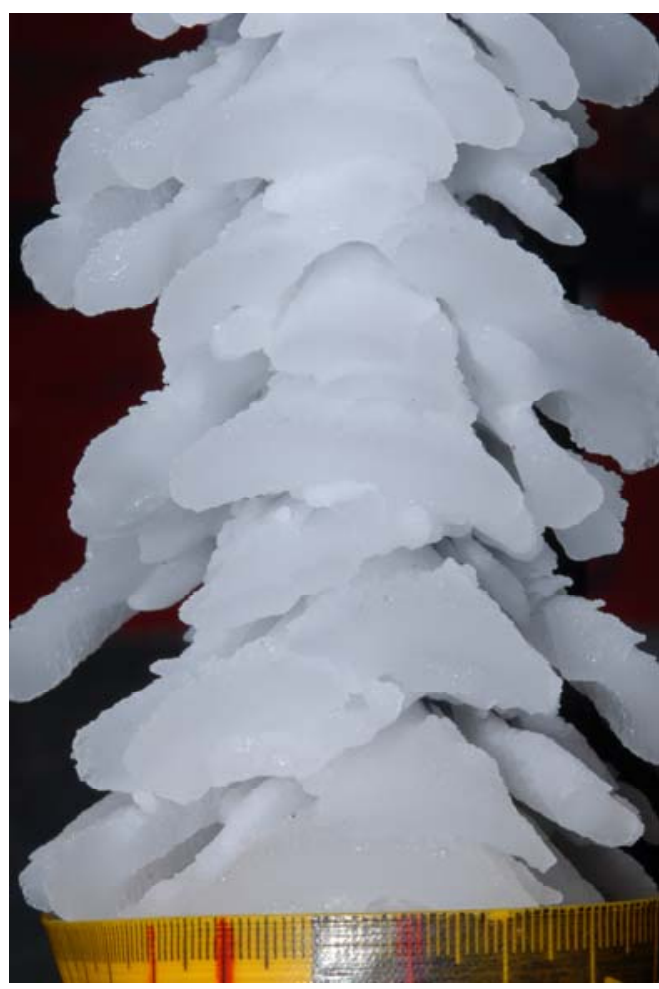

Figure 44.-Scallop structure after $10 \mathrm{~min}$. SLD condition of $\Lambda=45^{\circ}, V=172.7 \mathrm{mph}$, $\mathrm{T}_{\text {total }}=10^{\circ} \mathrm{F}, \mathrm{LWC}=0.75 \mathrm{~g} / \mathrm{m}^{3}, \mathrm{MVD}=$ $200 \mu \mathrm{m}, \tau=10 \mathrm{~min}$. Direction of flow is from bottom to top. Smallest scale on tape is $1 \mathrm{~mm}$. 


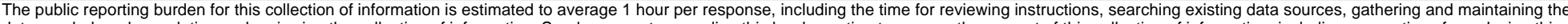

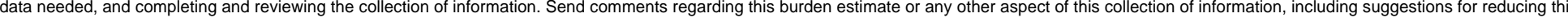

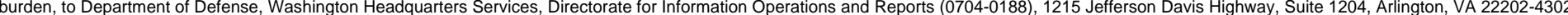

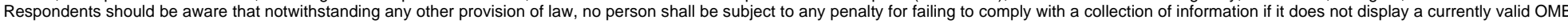
control number.

PLEASE DO NOT RETURN YOUR FORM TO THE ABOVE ADDRESS

\section{REPORT DATE (DD-MM-YYYY) \\ 2. REPORT TYPE \\ 3. DATES COVERED (From - To)}

01-12-2007

Technical Memorandum

\section{TITLE AND SUBTITLE}

Observations on the Growth of Roughness Elements Into Icing Feathers

\section{AUTHOR(S)}

Vargas, Mario; Tsao, Jen-Ching

\section{5a. CONTRACT NUMBER}

5b. GRANT NUMBER

5c. PROGRAM ELEMENT NUMBER

\section{5d. PROJECT NUMBER}

5e. TASK NUMBER

5f. WORK UNIT NUMBER

WBS 645846.02.07.03.04.01

\section{PERFORMING ORGANIZATION} REPORT NUMBER

E-16114

National Aeronautics and Space Administration

John H. Glenn Research Center at Lewis Field

Cleveland, Ohio 44135-3191

9. SPONSORING/MONITORING AGENCY NAME(S) AND ADDRESS(ES)

National Aeronautics and Space Administration

Washington, DC 20546-0001

\section{DISTRIBUTIONIAVAILABILITY STATEMENT}

Unclassified-Unlimited

Subject Category: 03

Available electronically at http://gltrs.grc.nasa.gov

This publication is available from the NASA Center for AeroSpace Information, 301-621-0390

\section{SPONSORINGIMONITORS ACRONYM(S) \\ NASA

11. SPONSORING/MONITORING
REPORT NUMBER
NASA/TM-2007-214932; AIAA-2007-
0900

\section{SUPPLEMENTARY NOTES}

\section{ABSTRACT}

This work presents the results of an experiment conducted in the Icing Research Tunnel at NASA Glenn Research Center to understand the process by which icing feathers are formed in the initial stages of ice accretion formation on swept wings. Close-up photographic data were taken on an aluminum NACA 0012 swept wing tip airfoil. Two types of photographic data were obtained: time sequence close-up photographic data during the run and close-up photographic data of the ice accretion at the end of each run. Icing runs were conducted for short ice accretion times from 10 to $180 \mathrm{sec}$. The time sequence close-up photographic data was used to study the process frame by frame and to create movies of how the process developed. The movies confirmed that at glaze icing conditions in the attachment line area icing feathers develop from roughness elements. The close-up photographic data at the end of each run showed that roughness elements change into a pointed shape with an upstream facet and join on the side with other elements having the same change to form ridges with pointed shape and upstream facet. The ridges develop into feathers when the upstream facet grows away to form the stem of the feather. The ridges and their growth into feathers were observed to form the initial scallop tips present in complete scallops.

\section{SUBJECT TERMS}

Ice accretions; Swept wings; Scallop formations

\begin{tabular}{|c|c|c|c|}
\hline \multicolumn{3}{|c|}{ 16. SECURITY CLASSIFICATION OF: } & \multirow{2}{*}{$\begin{array}{l}\text { 17. LIMITATION OF } \\
\text { ABSTRACT } \\
\text { UU }\end{array}$} \\
\hline $\begin{array}{l}\text { a. REPORT } \\
\text { U }\end{array}$ & $\begin{array}{l}\text { b. ABSTRACT } \\
\text { U }\end{array}$ & $\begin{array}{l}\text { c. THIS } \\
\text { PAGE } \\
\text { U }\end{array}$ & \\
\hline
\end{tabular}

18. NUMBER
OF
PAGES
29

19a. NAME OF RESPONSIBLE PERSON
STI Help Desk (email:help@sti.nasa.gov)
19b. TELEPHONE NUMBER (include area code)
301-621-0390



